HENRYK RUCIŃSKI (Białystok)

\title{
BRACTWA KOŚCIELNE I CECHOWE W KOPRZYWNICY DO 1795 ROKU
}

\section{Wstęp}

Koprzywnica, niewielka miejscowość w pobliżu Sandomierza, odznaczała się w okresie przedrozbiorowym dziejów Polski obfitością form i instytucji życia religijnego. Można się tu pokusić o porównanie ze stołecznym Krakowem w okresie od XIV do drugiej połowy XVI w. (sobór trydencki) ${ }^{1}$. Kraków był wówczas stolicą Królestwa Polskiego i aglomeracją miejską składającą się z samego Krakowa, Kazimierza i Kleparza, przy czym te dwie ostatnie miejscowości, przynajmniej formalnie, stanowiły odrębne organizmy miejskie. Do krakowskiej aglomeracji ciążyło też wiele pobliskich miejscowości.

Oczywiście porównywanie stołecznego Krakowa, będącego jednocześnie siedzibą jednej z najważniejszych w tamtejszej Polsce diecezji, z niewielką, znajdującą się w cieniu Sandomierza (ośrodka rozległej dzielnicy sandomierskiej) Koprzywnicą nie miałoby większego sensu. Chodzi tu tylko o uwypuklenie na tym tle bogactwa życia religijnego tej miejscowości.

Pozostaje kwestią otwartą, czy ta specyfika była efektem oddziaływania pobliskiego Sandomierza, czy wynikała $z$ inspiracji istniejącego tu jednego z najstarszych w Polsce klasztoru cysterskiego, który był właścicielem Koprzywnicy i rozległych dóbr w jej pobliżu. Cystersi z jednej strony nie tolerowali na swym terenie istnienia innych zakonów (choć wpływy tako-

1 H. Zaremska, Bractwa w średniowiecznym Krakowie. Studium form spotecznych zycia religijnego, Wrocław (Ossolineum) 1977. 
wych, zwłaszcza jezuitów sandomierskich w okresie nowożytnym są w Koprzywnicy zauważalne). Z drugiej strony w średniowieczu cystersi, jako zakon mniszy, programowo odcinali się od życia religijnego swych poddanych, tym bardziej że zakonnicy cysterscy przybyli z burgundzkiego Morimundu, a później, aż do XV w. przeważał wśród nich żywioł niemiecki. Poddani nie mogli nawet uczestniczyć w ceremoniach religijnych w cysterskim kościele. Dla nich zakonnicy wybudowali obok swej świątyni niewielki kościółek pod wezwaniem św. Leonarda ${ }^{2}$.

Dopiero w drugiej połowie XV w. zaznaczyła się zmiana. W 1491 r. opat Jan Breyner wraz z konwentem podnieśli kościół parafialny pod wezwaniem Wszystkich Świętych do godności prepozytury, powołując prepozyta i kolegium pięciu mansjonarzy oraz przeznaczając na ten cel odpowiednie środki. Kościółek św. Leonarda zburzono w 1529 r. Reformacja, a potem głęboki kryzys, jaki ogarnął Rzeczpospolitą po wojnach z połowy XVII w., spowodowały zmiejszanie się liczby mansjonarzy. W związku z tym zakonnicy cysterscy zaczęli pełnić w drugiej połowie XVII w. funkcje prepozytów i wikarych w kościele parafialnym. Na skutek tego prepozytura faktycznie wróciła do roli kościoła parafialnego. Z drugiej strony, odwrotnie niż w średniowieczu, cystersi zaczęli przymuszać parafian koprzywnickich do udziału w ceremoniach religijnych w swoim kościele klasztornym. Życie i instytucje religijne uległy ścisłemu powiązaniu $\mathrm{z}$ klasztorem ${ }^{3}$.

Z drugiej strony parafia koprzywnicka była normalną podstawową jednostką organizacy jną diecezji krakowskiej w archidiakonacie sandomierskim. Wpływ pobliskiego Sandomierza na Koprzywnicę nie ulega wątpliwości. Również położenie na ważnym szlaku handlowym z Krakowa do Sandomierza i dalej na wschód nie było tu bez znaczenia. Wyróżniała się też Koprzywnica liczbą jarmarków, których w połowie XVIII w. było 12. Trudno przesądzać, czy tak wielka liczba jarmarków była odbiciem znaczenia gospodarczego Koprzywnicy, czy raczej miała zapewnić wyjście z kolejnego kryzysu z pierwszej połowy XVIII w., spowodowanego wojną północną, wojną sukcesyjną po śmierci Augusta II Sasa i wielką zarazą, która objęła Europę Środkową w latach 1709-1711. W każdym razie jarmarki te ułatwiały kontakty Koprzywnicy ze światem i otwierały ją na panujące trendy gos-

2 Por. ks. J. Wiącek, Z przeszłości 4 kościotów koprzywnickich, Muzeum pamiątek po oo. Cystersach w Koprzywnicy, „Kronika Diecezji Sandomierskiej” 1958, nr 51.

3 Zagadnieniom tym poświęciłem oddzielne opracowanie - H. Ruciński, Prepozytura i kolegium mansjonarzy w Koprzywnicy na tle dziejów parafii do końca XVIII wieku, „Roczniki Humanistyczne” 1984, t. XXXII, z. 2. 
podarcze, jak na przykład instytucjonalizację rzemiosła w postaci wzrastającej liczby cechów rzemieślniczych, oraz trendy społeczne, których jednym z przejawów był szybki rozwój, między innymi, bractw kościelnych i cechowych.

Początki Koprzywnicy giną w pomroce dziejów. Od 1185 r. stała się własnością cystersów. Na ziemiach polskich cystersi, odmiennie niż na Zachodzie, nie osiedlali się w miejscach odludnych, tylko, ze względu na znikomą rolę konwersów, zakładali swe klasztory w miejscach zaludnionych, gdzie mogliby znaleźć środki do swej egzystencji ${ }^{4}$. Jest więc wysoce prawdopodobne, że miejscowość istniała tu przed przybyciem konwentu i założeniem opactwa cysterskiego, zwanego Clara provincia.

Już w 1250 r. Koprzywnica występuje jako osada targowa. Bolesław Wstydliwy w obszernym przywileju dla tej miejscowości, nadanym w r. 1262 po drugim najeździe tatarskim, wspomina, że już po pierwszym najeździe pogan (który miał miejsce w 1241 r.) otrzymał od niego klasztor koprzywnicki szereg przywilejów, dokument jednak wraz z całą osadą zozstał zniszczony. Widocznie więc po r. 1243 (objęcie władzy przez Bolesława Wstydliwego) uzyskała Koprzywnica prawo targu, co w przyszłości umożliwiło jej rozwój w charakterze ośrodka rzemieślniczego. Przywilej Bolesława Wstydliwego z 1262 r., wielokrotnie potwierdzany, zezwalał między innymi na sprowadzanie do Koprzywnicy ludzi wszelkiej narodowości i wszelkich zawodów, prócz Żydów. Być może, że zamożniejsi spośród rzemieślników koprzywnickich należeli do wymienionych w dokumencie "starszych" - seniores, którym zlecono pewne funkcje publiczno-prawne. W 15 lat później, w 1277 r., władca zwolnił zakonników koprzywnickich i mieszkańców osady od ceł na terenie podległych mu ziem, co mogło być w interesie zarówno rzemiosła koprzywnickiego jak i ewentualnych kupców, jeśli tacy tam wówczas egzystowali. Wcześniej, bo w 1268 r. uzyskała Koprzywnica prawa miejskie, co w przyszłości umożliwiło powstanie organizacji cechowej w tym miasteczku.

4 S. Epperlein, "Mit fundacyjny” niemieckich klasztorów cysterskich a relacja mnicha lubiaskiego z XIV wieku, „Przegl. Hist.” 1967, nr 58, z. 4, s. 587-604; J. Kłoczowski, Zakony na ziemiach polskich w wiekach średnich, w: Kościót w Polsce, Kraków 1968, t. I, s. 422-424; S. Trawkowski, Gospodarka wielkiej wtasności cysterskiej na Dolnym Ślasku w XIII wieku, Warszawa 1959, s. 41-43. Według wszelkiego prawdopodobieństwa cystersów sulejowskich osadził Kazimierz Sprawiedliwy w gródku książęcym leżącym przy starym romańskim kościółku, przy przeprawie przez Pilicę - J. Mitkowski, Początki klasztoru cystersów $w$ Sulejowie. Studia nad dokumentami, fundacja i rozwojem uposażenia do końca XIII wieku, „Poznańskie Towarzystwo Przyjaciół Nauk, Wydział Historii i Nauk Społecznych. Prace Komisji Historycznej”, t. XV, Poznań 1949, s. 177. 
Od XIII w. na czele miasta stał wójt. Nie wiadomo jednak, czy był on dziedzicznym, czy mianowanym przez opata. Mieszkańcy Koprzywnicy wystẹpu ją w niektórych dokumentach, jeszcze z drugiej połowy XIII w., jako cives, sama zaś osada nazywana jest civitas, co świadczy, że zaczęła nabierać charakteru miejskiego.

Nowe przywileje, gwarantujące miejski charakter osady, otrzymała Koprzywnica od Kazimierza Wielkiego za poparciem arcybiskupa gnieźnieńskiego Jarosława Bogorii Skotnickiego, który należał do grona ścisłych współpracowników monarchy, wywodził się zaś z rodu Bogoriów Skotnickich, niegdyś właścicieli Koprzywnicy i fundatorów tamtejszego klasztoru cysterskiego. Obok wójta, który wchodził w skład sądu wyższego prawa niemieckiego grodu sandomierskiego, występuje w Koprzywnicy ława miejska, jako sąd pierwszej instancji dla mieszkańców miasteczka, których liczba sięgała około 800. W latach dwudziestych XV w. istniała w Koprzywnicy rada miejska. W tym samym czasie Władysław Jagiełło nadał Koprzywnicy prawo do odbywania jarmarku (prawo targowe miała już w połowie XIII w.). Z przywileju jarmarcznego Władysława Jagiełły z 1428 r. wynika, że Koprzywnica była znacznym ośrodkiem wyrobu sukna. Istnieją w literaturze dotyczącej Koprzywnicy wzmianki, niestety nie potwierdzone źródłowo, że w 1430 r. pojawił się w miasteczku pierwszy cech rzemieślniczy - kowalski. W tym samym roku biskup Zbigniew Oleśnicki erygował tu piewsze bractwo kościelne. Proces wykształcania się ustroju miejskiego Koprzywnicy w ten sposób został zakończony ${ }^{5}$.

Parafia koprzywnicka ma dawną metrykę. Wyrażano poglądy, że mogła ona powstać jeszcze przed przybyciem cystersów. Nie zgadza się z tymi poglądami Zofia Kozłowska-Budkowa, która jak dotąd najbardziej kompetentnie wypowiedziała się na temat początków parafii koprzywnickiej. Co prawda pierwsza wzmianka źródłowa na temat tej parafii pochodzi dopiero z 1326 r., ale parafia jest znacznie starsza. Według autorki, która przytacza na ten temat szereg argumentów, miała ona powstać po przybyciu konwentu cysterskiego do Koprzywnicy, najpóźniej w 1268 r. Pierwotnym kościołem parafialnym miałby być kościół św. Leonarda. W trakcie przekształcania się pod wpływem prawa niemieckiego, nadanego w 1268 r., osady targowej

5 H. Ruciński, Poczatki Koprzywnicy do wyksztatcenia się ustroju miejskiego na tle innych ośrodków miejskich Matopolski, „Rocznik Muzeum Narodowego w Kielcach” 1980, t. 11, s. 115-141; tenże, Cechy rzemieślnicze w Koprzywnicy do 1795 r., „Zeszyty Naukowo-Dydaktyczne Filii Uniwersytetu Warszawskiego w Białymstoku", z. 12, Humanistyka, t. III, Białystok 1975, s. 102-103. 
w miasto, które powstało w pewnym oddaleniu od klasztoru, zbudowano przy rynku nowy kościół pod wezwaniem Wszystkich Świętych, który przejął funkcje kościoła farnego. Według świadectwa Jana Długosza z drugiej połowy XV w. był on murowany. Kościół św. Leonarda stał się zbyteczny i został rozebrany ${ }^{6}$. W 1491 r., jak wspomniano wyżej, kościół farny w Koprzywnicy został podniesiony do godności prepozytury z kolegium 5 mansjonarzy.

Koprzywnica stała się typową dla późnego średniowiecza strukturą zwaną communitas lub universitas, na którą składały się mniejsze społeczności, również nazywane communitates lub universitates, które były grupami ludzi połączonymi specjalnymi więzami (por. nasz uniwersytet, czyli społeczność uczących się i nauczających), które wchodziły w skład większej społeczności (powszechności) - communitas civitatis.

Na tak zarysowanym tle formowania się organizmu miejskiego i rozwoju parafii w Koprzywnicy można przejść do właściwego zagadnienia, to jest omówienia roli bractw kościelnych i cechowych, które będą przedstawiane w kolejności chronologicznej.

\section{Bractwa kościelne}

\section{a. Bractwo literackie}

8 czerwca 1430 r. biskup Zbigniew Oleśnicki w Złotej pod Sandomierzem erygował bractwo ubogich na prośbę rektora kościoła parafialnego oraz przezornych (providi) mężów Klemensa, Tomasza, wójta Jakuba, Stanisława Patoki, Piotra Gospodarczyka i Pawła Luczki z Koprzywnicy oraz innych wiernych płci obojga $z$ parafii koprzywnickiej ${ }^{7}$. Dzieje i rolę tego bractwa omówiłem $w$ odrębnym opracowaniu ${ }^{8}$. Nie ma więc powodu, żeby tu sze-

6 Z. Kozłowska-Budkowa, S. Szczur, Dzieje opactwa cystersów w Koprzywnicy do końca XIV wieku, „Nasza Przeszłość” 1983, nr 60, s. 35-36. Autorzy uzupełniaja, precyzują lub nie zgadzają się z niektórymi sformułowaniami z mojego wyżej wymienionego artykułu na temat początków Koprzywnicy. Ponieważ są to sprawy drugorzędne, omawianie ich i polemizowanie $w$ niniejszym opracowaniu, poświęconemu innym zagadnieniom, nie miałoby większego sensu.

7 Fraternitas pauperum - Zbiór dokumentów katedry i diecezji krakowskiej, cz. II, 1416-1450, wyd. Stanisław Kura.ś, Towarzystwo Naukowe KUL, Lublin 1973, s. 158, n 298.

8 H. Ruciński, Bractwo literackie w Koprzywnicy jako obraz struktury spotecznej miasteczka w latach 1694-1795, „Przegl. Hist.” 1974, t. LXV, z. 2, s. 263-283. 
rzej się nad nim rozwodzić. Niemniej warto przytoczyć kilka refleksji, które w cytowanym artykule niedostatecznie zostały uwzględnione ${ }^{9}$.

Jeśli chodzi o osoby, na których prośbę biskup erygował bractwo, po rektorze fary wymieniono, przed wójtem, Klemensa i Tomasza. Czy byli to ludzie szczególnie zaangażowani w powołanie konfraterni, a wójta wymieniono po nich ze względu na jego funkcję w miasteczku, czy byli to witrycy kościoła parafialnego - trudno dzisiaj przesądzać. Według badań Hanny Zaremskiej, w aglomeracji krakowskiej (Kraków, Kazimierz, Kleparz) jakieś jedno bractwo opanowywała grupa członków najbardziej reprezentatywnego rzemiosła lub rzemiosł i szczególną rolę odgrywali w takiej konfraterni członkowie władz miejskich. Dzięki temu bractwo nabierało charakteru elitarnego, aczkolwiek dostęp do niego mieli wszyscy, którzy spełnili określone warunki (głównie chęć przyjęcia obowiązków wynikających ze wstąpienia do bractwa i opłata „wpisowego", często zróżnicowana ze względu na status majątkowy wstępującego ${ }^{10}$. Istotnym powodem wstępowania do konfraterni były nadane bractwu indulgencje (odpusty), które miały chronić od wiekuistego potępienia i ułatwiać zbawienie zmarłym członkom bractwa oraz obowiązek wszystkich jego członków do udziału w pogrzebie zmarłego współbrata i modłów za jego duszę ${ }^{11}$. Podnosiło to w jakiś sposób prestiż członków bractwa i powodowało chęć przynależności doń przedstawicieli władz miejskich, którzy opanowywali w bractwie funkcje kierownicze.

Innym znamiennym rysem był od XIV w., a nasilający się w stuleciu następnym, wzrost kultu maryjnego, który przejawiał się między innymi w otaczaniu szczególną czcią wizerunków NMP ${ }^{12}$.

Pierwotne bractwo ubogich w Koprzywnicy już w 1472 r. nosiło nazwę Fraternitas fratrum sub titulo literatorum in oppido Koprzywnica, a w XVIII w. określano je jako communitas eiusdem civitatis. Nowe bractwo ubogich powstało w 1496 r. ${ }^{13}$ Święto patronalne konfraterni przypadało na

9 Pierwsza wersja znajduje się w maszynopisie mojej pracy doktorskiej: Struktura miasteczka w okresie feudalnym na przyktadzie Koprzywnicy, Toruń 1970. Maszynopis w Bibliotece Uniwersytetu M. Kopernika w Toruniu, promotor prof. dr hab. Karol Górski, recenzje (odpisy w posiadaniu Towarzystwa Przyjaciół Koprzywnicy) prof. dra hab. Józefa Mitkowskiego i prof. dra hab. Henryka Samsonowicza. W odniesieniu do bractwa literackiego oparłem się częściowo na materiałach, które do swego wyżej wzmiankowanego wydawnictwa wykorzystał Stanisław Kuraś.

10 H. Zaremska, op. cit., s. 56 i 101.

11 Ibidem, s. 138.

12 Ibidem, s. 130 i 134.

13 H. Ruciński, Bractwo literackie..., s. 266. 
15 sierpnia - Wniebowzięcie NMP. Przez całe osiemnaste stulecie członkowie bractwa zbierali fundusze na nowy obraz NMP w kościele farnym oraz na srebrną sukienkę do tego obrazu ${ }^{14}$.

Innym problemem jest oddziaływanie na bractwo literackie w Koprzywnicy sodalicji mariańskiej, kierowanej od drugiej połowy XVI w. przez jezuitów. Źródła historyczne nie wspominają o takim oddziaływaniu. Jednak w pobliskim Sandomierzu istniał znaczny ośrodek jezuicki. Sugestię takiego oddziaływania na podstawie pewnych podobieństw w sprawowaniu kultu w bractwie koprzywnickim wysunął w recenzji mojej pracy doktorskiej prof. Józef Mitkowski, znawca zagadnień związanych z kultem i organizacjami Kościoła rzymsko-katolickiego. Zagadnienie to wymagałoby jednak pogłębionych badań.

\section{b. Bractwo ubogich}

Drugim chronologicznie bractwem ${ }^{15} \mathrm{w}$ Koprzywnicy było bractwo ubogich. Powstało ono po ostatecznym przekształceniu się pierwotnego bractwa ubogich z 1430 r. w bractwo literackie oraz po założeniu szpitala w Koprzywnicy. Założyciele w porównaniu z założycielami bractwa z r. 1430 rzeczywiście rekrutowali się z warstw uboższych.

Na prośbę Michała rajcy, Mikołaja ślusarza (serifex), Stanisława Węcławka (Wanclawek), Łukasza Jęto (Janto), Andrzeja Kopcia, Klemensa Kozła, Stanisława Burka wójta ubogich (advocatus pauperum), Jana Boji, Agnieszki Świstowej, Elżbiety Parzyszczkowej, Elżbiety Kantorowej i innych braci ubogich (fratrum pauperum) kardynał prymas i biskup krakowski Fryderyk Jagiellończyk zatwierdził bractwo 17 IX 1496 r. w Kunowie ${ }^{16}$. Według

14 Tak długi okres tego przedsięwzięcia wynikał głównie z nieudolności, a niekiedy wręcz złej woli starszyzny brackiej. Zdarzały się defraudacje pieniędzy przeznaczonych na ten çel. W każdym razie w bractwie zaistniało zaobserwowane przez Hannę Zaremską zjawisko - kult maryjny odgrywał istotną rolę w koprzywnickim bractwie literackim.

$15 \mathrm{O}$ związku bractw ubogich i żebraków ze szpitalami - ks. Bolesław Kumor, Kościelne stowarzyszenia świeckich na ziemiach polskich $w$ okresie przedrozbiorowym, „Prawo Kanoniczne” 19 (1967), nr 1-2, s. 321-322; G. Matern, Die Elenbruderschaften im alten Ermland, „Pastoralblatt für die Diözese Ernland” 2 (1906), s. 19, nie zdołał ustalić, czy na Warmii bractwa ubogich opiekowały się szpitalami, stwierdza jednak, że głównym celem bractw ubogich było grzebanie żebraków z przytułków i ofiar zarazy (ibidem, s. 18), a w Wartenburg starsi bractwa byli prowizorami szpitalnymi (ibidem, s. 20. H. Zaremska, op. cit., s. 106 i n.

16 Kodeks koprzywnicki (kopiarz kościoła parafialnego w Koprzywnicy), s. 15-16. Data roczna wystawienia dokumentu: millesimo quadringentesimo sexto. Jest to błąd oczywisty kopisty, w innych przekazach sprostowany. 
dokumentu erekcyjnego bracia i siostry, piśmienni i niepiśmienni, którzy zapisali się do bractwa (Fraternitatis Pauperum) mieli przybywać na pogrzeby zmarłych braci i sióstr, śpiewać 15 Pater noster, tyleż Ave Maria i jedno Credo, chyba że zaistniałaby istotna przeszkoda. Jeśliby zaś w szeregach bractwa znalazł się kapłan, winien za zmarłego konfratra śpiewać wigilie 9 lekcji i mszę żałobną lub requiem. Postara się też bractwo, aby w każde Suche dni kapłan - członek bractwa lub wikary z rektorem szkoły odśpiewali w kościele parafialnym w Koprzywnicy wigilie z 9 lekcjami i laudesami oraz mszę żałobną, natomiast bracia odmówią wówczas 5 Pater noster, 5 Ave Maria i jedno Credo. We wszystkich zmartwieniach bracia powinni sobie nawzajem pomagać, zwłaszcza przez modlitwę ${ }^{17}$. Wobec tego bracia mają zatroszczyć się, aby co tydzień odbywały się 2 msze czytane przez księdza brackiego lub wikarego, jedna za grzeszników w środy i druga za zmarłych w piątki. Mogli też bracia, zwyczajem innych bractw, na pierwszych nieszporach i uroczystych mszach trzymać zapalone świece, jeśliby takie posiadali. Kardynał określił również podstawy finansowe bractwa oraz jego władze. Wszyscy członkowie bractwa mieli 4 razy do roku w Suche dni złożyć po pół grosza na ręce cechmistrzów (in manus cechmagistrorum). Pieniądze zebrane mieli przechowywać starsi bractwa (seniores fratres), w tym celu wybrani. Nie wiadomo, czy seniorzy i cechmistrze to te same osoby, jak w bractwie literackim. W każdym razie znów nazwa ich - cechmistrz, jest znamienna. Fundusze miano przeznaczać na potrzeby bractwa i kościoła parafialnego. Nadał też kardynał braciom 100 dni odpustu, zezwalając jednocześnie na nadawanie odpustów bractwu przez innych biskupów.

Następny odpust otrzymało bractwo równocześnie $z$ bractwem literackim od prymasa Andrzeja Róży Boryszewskiego 23 VIII 1508 r. Ciekawe, że więcej odpustów bractwo nie dostało, choć niejednokrotnie rozmaici biskupi (') darzali indulgencjami bractwo literackie i sodalicję kapłańską w KoprzywLis.y.

Nie ma w przywileju erekcyjnym mowy o możności przyjmowania nowych członków, nie wpływało to jednak z pewnością na, żywotność bractwa i było raczej wynikiem przeoczenia..

Przywilej bractwa ubogich był bardziej dostosowany do ludzi biednych od przywileju z r. 1430. Wskazują na to nie tylko niższe opłaty, ale również większa troska o zmarłych i żywych, przejawiająca, się w cotygodniowych

17 Caeterum cum in omnibus eorum necessitatibus, afflicationibus, gravantibus suffragari subvenireque necesse est. 
mszach za zmarłych i grzeszników. Nie było też odrębnych obowiązków dla piśmiennych i analfabetów. W sumie człowiek ubogi bez specjalnych legatów dla bractwa miał zapewnioną określoną ilość modlitw i mszy za zbawienie swej duszy.

Również skład założycieli bractwa ubogich zdecydowanie różni się od składu osób zakładających bractwo w 1430 r. O ile wówczas występowali wraz z rektorem kościoła „patrycjusze” koprzywniccy, poświadczani kilkakrotnie źródłowo, w r. 1496 wystąpił tylko jeden rajca ${ }^{18}$, jeden rzemieślnik i szereg osób o nieokreślonej profesji, w tym kilka kobiet, wypadek raczej odosobniony $\mathrm{w}$ średniowiecznej praktyce. Prawdopodobnie opiekowały się one ubogimi, zwłaszcza kobietami w szpitalu. Na szczególną uwagę zasługu je wymieniona na dalszym miejscu postać Stanisława Burka, wójta ubogich. Określenie takie występuje w Koprzywnicy jeszcze jeden raz, ale dopiero w 1689 r., po zaniku bractwa ubogich. 27 maja tego właśnie roku rodzicami chrzestnymi dziecka z pobliskiego, należącego do parafii koprzywnickiej Krzcina byli Stanisław Siko (? - nazwisko nieczytelne) advocatus pauperum i Elżbieta (nazwisko nieczytelne) alias baba ${ }^{19}$. Prawdopodobnie był on starszym żebraków lub pensjonariuszy szpitala koprzywnickiego ${ }^{20}$.

18 W Anklam i na Rugii często do bractw ubogich wstępowała szlachta - Hellmuth Heyden, Bruderschaften, Häuser und Altäre der Elenden in Pommern (Ein Beitrag zur Geschichte der Fremderfürsorge im Mittelalter), „Baltische Studien” (Neue Folge), t. 50 (1964), s. 45.

19 Metryka chrztów, do niedawna na plebanii kościoła parafialnego w Koprzywnicy, sub dato. Założycielami tzw. bractwa żebraków przy kościele Wszystkich Świętych w Krakowie w r. 1433 byli witrycy, w średniowieczu z reguły rajcy i żebracy - Eugeniusz Wiśniowski, Bractwa religijne na ziemiach polskich w średniowieczu, „Roczniki Humanistyczne", t. XVII (1969), z. 2, s. 66. H. Zaremska, op. cit., s. 108, podaje, że według tekstu dyplomu z 1433 r. dla wyżej wymienionego bractwa wśród inicjatorów było dwóch żebraków (pauperes homines et mendici). W pół roku później bractwem zarządzali wyłącznie rzemieślnicy.

20 Według ordynacji powizytacyjnej ks. Jana Januszowskiego z 1608 r. w Nowym Targu ubodzy mieszkający w szpitalu i żebrzący przy kościele parafialnym mieli swojego starszego - seniora, który wraz z witrykami rozdzielał wśród nich jałmużnę ze skrzynki (skarbony), karał ich itp. - Acta visitationes capituli w Archiwum Kurii Metropolitalnej w Krakowie (cyt. dalej: AV), t. 25, 1608 r., s. 64. W Krakowie w początkach XVI w. pojawia się prefectus pauperum, który miał pomocnika zwanego advocatus pauperum. Sprawowali oni kontrolę i opiekę nad najuboższymi warstwami w mieście. Na Kleparzu natomiast w 1544 r. pojawił się nowy urzędnik - iudex pauperibus - H. Zaremska, op. cit., s. 109. W 1780 r. w Krakowie władze miejskie w celu ściślejszej kontroli nad żebrakami ustanowiły tzw. betelfochtów, czyli starszych dziadów lub wójtów żebrackich. Nazwa wzięła się z niemieckiego: Bettelvogt. Do połowy XIX w. zwano ich pogardliwie krakowskimi oberdziadami - A. Chmiel, Szkice krakowskie, „Biblioteka Krakowska” nr 100, Kraków 1939-1947, s. 88. Według artykuliku Redakcji „Mówią wieki” 1970, nr 5, s. 32, urząd wój- 
Konieczność powołania nowego bractwa ubogich w miejsce tego, które w 1430 r. założył biskup Oleśnicki i które wkrótce przekształciło się w bractwo literackie, wzięła się stąd, że biskup miał, prawdopodobnie ze względu na wpływy idące w pierwszej połowie XV w. z Niemiec, predylekcję do zakładania bractw ubogich, których szereg erygował na terenie swej diecezji ${ }^{21}$. Nie zawsze było to zgodne ze stosunkami miejscowymi i pierwotne bractwa ubogich zmieniały swój charakter.

Bractwo ubogich z 1496 r. nie rozwijało się. W 1646 r. nie przejawiało już żadnej działalności. Prepozyt obiecał zająć się bractwem ${ }^{22}$, ale usiłowania te, zdaje się, nie odniosły żadnego skutku. Według wizytacji z r. 1727 bractwo ubogich opiekowało się ołtarzem św. Józefa w kościele parafialnym ${ }^{23}$. Podobnie było w r. $1748^{24}$. W kilkanaście lat później ołtarz ten przeszedł pod opiekę cechu tkaczy ${ }^{25}$. Już jednak w r. 1700 kopię pergaminowego przywileju bractwa ubogich przechowywało w swej skrzyni bractwo literackie. Oryginał już wówczas nie istniał ${ }^{26}$.

Ciekawe, że zanik bractwa nastąpił w okresie, gdy bractwa tego rodzaju przeżywały w XVIII w. po zubożeniu kraju wielki rozkwit ${ }^{27}$.

W konkluzji należy zauważyć, że bractwo ubogich w Koprzywnicy nie dorównywało tego rodzaju bractwom na terenach bardziej rozwiniętych gospodarczo, jak Warmia czy Pomorze Zachodnie. O ile bractwo ubogich w Koprzywnicy starało się zapewnić odpowiedni pogrzeb i modlitwy własnym,

tów żebraczych - betelfochtów - miano wprowadzić po raz pierwszy w Gdańsku w 1551 r. W takim razie wójtowie ubogich w Koprzywnicy, jeśli byliby starszymi żebraków, pojawili się o prawie wiek wcześniej. W Koprzywnicy patronat nad powstałym w 1473 r. szpitalem i jego pensjonariuszami sprawowała przez swych prowizorów rada miejska, podobnie zresztą jak w szeregu innych miejscowości: H. Ruciński, Szpital w Koprzywnicy (XV-XVIII wiek). Materiaty do dziejów spoteczno-religijnych w Polsce, pod red. Z. Sułowskiego i E. Wiśniowskiego, KUL Lublin 1974, s. 99.

21 H. Zaremska, op. cit., s. 107.

22 AV, t. 7 (1646), s. 11.

$23 \mathrm{AV}$, t. $22(1727)$, s. 126.

24 AV, t. 46 (1748), s. 277.

25 AV, t. 51 (1765), s. $223 \mathrm{v}$.

26 Księga bractwa literackiego na plebanii w Koprzywnicy, s. 3. Tamże mylna data dzienna - 23 sierpnia. Jest to data nadania bractwu w 1508 r. odpustu.

27 Ks. B. Kumor, Kościelne stowarzyszenia..., s. 325 i n.; tamże mowa o zarządzeniu prymasa Michała Poniatowskiego o wprowadzeniu tych bractw we wszystkich parafiach. $\mathrm{Na}$ Warmii jednak bractwa ubogich od XVI w. uległy zwyrodnieniu. Za przykładem cechów rozpowszechniło się w bractwach opilstwo (piwo), tańce zapustne, a nawet strzelanie do tarcz - G. Matern, op. cit., s. 20, a o bractwie w Dobrym Mieście (Guttstadt): ibidem, s. 19, o bractwach pijackich (Trinkgesellschaft): ibidem, s. 18. 
raczej niezamożnym członkom, bractwa ubogich na Warmii przed reformacją, a więc przed swym upadkiem, miały zajmować się przede wszystkim grzebaniem wędrowców, pielgrzymów i bezdomnych ${ }^{28}$. W Małopolsce jedynie statut bractwa w Skaryszewie, choć nie nosi ono nazwy bractwa ubogich, przewidywał grzebanie ubogich i pielgrzymów ${ }^{29}$. W XVI i XVII w. bractwa ubogich na wsiach pomagały pogorzelcom, udzielając im pomocy w żywności, paszy i odbudowie ${ }^{30}$.

\section{c. Bractwo kapłańskie}

Konfraternie kapłańskie były na ziemiach Rzeczypospolitej przedrozbiorowej zjawiskiem raczej rzadkim. Bractwa te zrzeszały w swych szeregach również osoby świeckie, których liczba często przewyższała stan liczebny kleru ${ }^{31}$. Dzięki temu zwiększał się znacznie zasięg oddziaływania tego rodzaju korporacji.

Dokumenty dotyczące sodalicji kapłańskiej w Koprzywnicy, zredagowane w języku łacińskim, zachowały się w Kodeksie koprzywnickim. Jest to ręcznie pisany kopiarz dokumentów erekcy jnych prepozytury koprzywnickiej i bractw przy niej istniejących. Zawiera też wyciągi z ksiąg miejskich, dotyczące zapisów dla tejże prepozytury i mansjonarzy. Sporządził go w latach 1665-1667 prawdopodobnie jeden z prepozytów koprzywnickich, zarazem mnich cysterski, celem rewindykacji czynszów należnych kościołowi parafialnemu ${ }^{32}$. Odpisy dokumentów odnoszących się do sodalicji znajdują się na stronach 16-20 Kodeksu.

Akt erekcyjny sodalicji, zawierający jej statut, wystawił 22 X 1534 r. biskup krakowski Piotr Tomicki, podkanclerzy Królestwa Polskiego, w obecności Jerzego Miszowskiego, doktora obojga praw, i kanclerza kurialnego, Stanisława Borka archidiakona, Benedykta Istbińskiego i Samuela Maciejowskiego kanoników katedralnych krakowskich oraz dwóch szlachciców: Sta-

28 G. Matern, op. cit., s. 18. H. Heyden, op. cit., s. 47, wy jaśnia, że termin ubogi (elend) odpowiadał $\mathrm{w}$ średniowieczu łacińskiemu exul, patrz także G. Matern, op. cit., s. 1.8 .

29 Zbiór dokumentów katedry..., s. 222, nr 343.

30 G. Matern, op. cit., s. 21.

31 B. Kumor, Kościelne stowarzyszenia..., s. 306; E. Wiśniowski, op. cit., s. 59, 66-67; Hellmuth Heyden, Kirchengeschichte Pommerns, t. I, Von den Anfängen des Christentums bis zur Reformationszeit, 2. Aufl., Köln - Braunsfeld 1957, s. 164.

32 H. Ruciński, Struktura miasteczka..., s. 7; tenże, Bractwo literackie w Koprzywnicy..., s. 264-265. 
nisława Dąbińskiego i Jana Garlicza. Dokument ten uwierzytelnił notariusz publiczny Nikodem Jan Przyjemski, jako kleryk diecezji włocławskiej i notariusz biskupi zarazem przykładając pieczęć.

Dokument rozpoczyna szablonowa arenga z cytatem Ewangelii św. Jana $(13,34)$. W następnej kolejności występu ją założyciele sodalicji: Stanisław z Wiślicy - prepozyt koprzywnicki i pleban połaniecki, oraz Grzegorz z Nowego Miasta Korczyna - pleban w Zborówku. Obaj duchowni powodowani miłością, pragnąc dostąpić większych łask Bożych i odpuszczenia grzechów dla siebie i swoich najbliższych, modlitwami, postami, wszelkimi cnotami, dziełami pobożnymi i służbami praktykowanymi w bractwie duchowym (in fraternitate spirituali), zwrócili się w imieniu swoim i kapłanów (urzędujących i nie urzędu jących) $\mathrm{z}$ archidiakonatu sandomierskiego i wiślickiego oraz dekanatu ksiąskiego do ordynariusza Tomickiego z prośbą o założenie sodalicji (mutua in Domino sodalitas), obdarzenie jej łaskami i przywilejami oraz zatwierdzenie statutu postanowionego i przestrzeganego przez braci w bractwie (fratres in fraternitate) wraz z przepisami, które uchwalą ewentualnie $\mathrm{w}$ przyszłości. Biskup zezwolił na wstępowanie i zapisywanie się do bractwa prezbiterom urzędującym i nie urzędującym, duchownym uposażonym i nie uposażonym, ze święceniami wyższymi i niższymi z wyżej wymienionych archidiakonatów i dekanatu oraz wszystkim duchownym $z$ całej diecezji krakowskiej, jak również $\mathrm{z}$ innych diecezji (se ascribere et incorporare postulaverint). Bractwo otrzymało wezwanie NMP Bożej Rodzicielki, którą bracia obrali sobie za patronkę.

Treść statutu zredagowana tak, jak i inne tego rodzaju dokumenty, bez podziału na punkty, jest następu jąca:

Bracia zebrani w odpowiednim miejscu będą wybierać dwóch rektorów sodalicji jako starszych (duos rectores sodalitii huius modi in seniores), którzy winni kierować braćmi, zachowywać statuty i uchwały brackie, przechowywać zebrane składki (tributum) oraz dbać o bractwo i przestrzegać jego zarządzeń.

Kadencja starszych miała trwać rok, po upływie którego dotychczasowi starsi lub jeden $\mathrm{z}$ nich mogli zostać wybrani ponownie. Stylizacja tego dokumentu sugeruje jednak, że wybieranie należało do starszych, a pozostali bracia jedynie mogli ten wybór akceptować. Starszym należało się posłuszeństwo ze strony braci.

W każde Suche dni miał się odbywać „kongres” (Congressus) w miejscu i czasie ustalonym przez bractwo (per totam sodalitii fraternitatem). Po wyczerpaniu porządku obrad i podjęciu konkluzji zostanie wyznaczony następny kongres. Miejscem jego może być jakieś miasto lub miasteczko (in 
loco civitati vel oppidi alicuius). O kongresie członkowie bractwa zostaną dodatkowo powiadomieni przez starszych (rectores seu seniores fratres) listownie, $\mathrm{z}$ tym że list ma być przekazywany $\mathrm{z}$ rąk do rąk. W ten sposób również bracia nieobecni na ostatnim kongresie zostaną powiadomieni o czasie i miejscu następnych obrad.

Członkowie bractwa w swoich kościołach podczas niedzielnych kazań powinni propagować sodalicję i jej przedsięwzięcia, aby wierni wspomagali ją modlitwami, jałmużnami i innymi dobrymi uczynkami.

Kongres rozpoczną bracia od mszy świętej śpiewanej do Ducha Świętego, prosząc o łaskę dla siebie i całego chrześcijaństwa (pro sancta Respublika christiana) oraz dla jego duchownych i świeckich rządców, szczególnie papieża. Będą się też modlić za króla i Królestwo Polskie, za jego chrześcijańską ludność, a przede wszystkim o obronę Królestwa od zbrojnych nieprzyjaciół. Następnie odśpiewają wigilie 9 lekcji i mszę św. wraz z procesją za zmarłych braci i siostry sodalicji. Potem jeden $z$ braci wygłosi do ludu kazanie w języku polskim (sermone vulgari) o stanie chrześcijaństwa i „sławnej sodalicji”, polecając ją modlitwom. Po kazaniu odbędzie się msza solenna o NMP jako patronce sodalicji, wreszcie wszyscy bracia kapłani odczytają po dwie msze prywatne. W czasie tych uroczystości bracia wystąpią w komżach i stułach, ze świecami w ręku, chwaląc Boga psalmami i hymnami. Po nabożeństwie i usunięciu spomiędzy siebie wszystkich obcych (extraneis quibuslibet - w tym chyba również braci i sióstr świeckich) bracia zamknięci w kościele rozpoczną obrady oraz złożą na ręce kolektora spośród starszych (collectoris seniorum fratrum) składkę ustanowioną na potrzeby sodalicji.

W przypadku obłożnej choroby brata inni, którzy się do tego zobowiążą, powinni do niego przybyć, podjąć się wykonania testamentu, tudzież zaopatrzyć umierającego, a w razie śmierci, wezwawszy do pomocy członków sodalicji z sąsiedztwa, pogrzebać i spełnić ostatnią wolę zmarłego oraz odprawić nieszpory, wigilie 9 lekcji i mszę za zmarłych lub zlecić odprawienie tych nabożeństw innym. Natomiast świeccy, gdyby do tej sodalicji (collegium sodalitii) należeli, zmówią i odśpiewają za zmarłego 15 Ojcze nasz..., tyleż Zdrowaś Mario... i jedno Wierzę w Boga....

Powyższe modlitwy odmówią wszyscy bracia, tak duchowni jak i świeccy, sami lub przez zastępców w każde Suche dni za dusze wszystkich braci, sióstr i dobroczyńców sodalicji.

Biskup Tomicki zaaprobował statut oraz ewentualne zmiany, jakie w przyszłości mogłyby być wprowadzone na kongresach, jednak bez naruszania praw i jurysdykcji ordynariusza, archidiakona i oficjała. Ponadto 
1aalał 40-dniowy odpust ki ż ( razowo wszystkim osobom obojga płci, zapisującym się do bractwa, p"èrzegającym obowiązków i zwyczajów brackich, ofiarującym bractwu ucciług swej możności różne dary, a zwłaszcza paramenty, księgi ilustrowane i kielichy, nawiedzającym kościół lub miejsce, w którym odbywałyby się uroczystości brackie, biorącym udział osobiście lub przez zastępców w pogrzebach braci i egzekwiach, żałującym za grzechy, pokutującym, wyspowiadanym lub pragnącym się wł. spowiadać.

Wyraził też zgodę, by inni dostojnicy kościelni udzielali bractwu odpustów. Takich odpustów 40-dniowych sodalicja otrzymała jeszcze osiem. Przy wyszczególnieniu ich nie zachowano porządku chronologicznego. Wyliczam je więc w porządku faktycznym:

1. 13 X 1537 r. w Koprzywnicy - Dominik Małachowski, profesor teologii, biskup laodycejski, sufragan krakowski - członkom bractwa ${ }^{33}$. Notariusz - Stanisław z Wiślicy.

2. Walerian, biskup margaretański, sufragan kujawski (sic!) - braciom i innym osobom. Notariusz - Stanisław z Wiślicy.

Brak daty nadania tego odpustu. Osoba notariusza publicznego jak i kolejność przytoczenia pozwalają przypuszczać, że został on nadany między 1537 a 1539 r. Miejsca nadania nie podano.

3. 21 II 1540 r. - Samuel, biskup chełmski, podkanclerzy Królestwa - przestrzegającym statutu sodalicji. Notariusz kurialny - Tomasz Konopnicki. Miejsca nadania nie podano.

4. 2 V 1539 r. w Krakowie - Stanisław Tarło, biskup przemyski, i Sebastian Branicki, biskup chełmski - wszystkim wyspowiadanym, wspierającym sodalicję i czyniącym zadość jej statutowi w całości lub części (tam in parte quam in toto). Notariusz - Stanisław Simonis z Wiślicy.

5. 17 II 1540 r. w Krakowie - Jan (Latalski - dop. H.R.), arcybiskup gnieźnieński, legat urodzony i prymas Królestwa - za wypełnianie statutu. Notariusz publiczny kurii arcybiskupiej - Piotr Bocimiński.

6. 20 II 1540 r. - Piotr (Gamrat - dop. H.R.), biskup krakowski za wypełnianie statutu. Notariusz kurialny - Achacy Grzymała. Miejsca nadania nie podano.

33 W tym samym dniu bractwo literackie w Koprzywnicy otrzymało od biskupa Małachowskiego odpust, nie zostało natomiast obdarowane odpustem istniejące tamże bractwo ubogich. 
7. Tegoż samego dnia - 20 I] 5 ¿ll r. - Jakub, biskup płocki - za wypełnianie statutu. Notariusz kurialı! - Jakub Sobolewski. Miejsca nadania nie podano.

8. 1 XII 1539 r. w Krakowie - biskup Piotr (Gamrat - dop. H.R.) wraz z. zatwierdzeniem uzyskanych odpustów i nadaniem nowego, żeby bractwo rozkwitało, a osoby płci obojga zapisywały się do niego i wspomagały uczynkami wymienionymi uprzednio przez biskupa Tomickiego, znacznie rozszerzył prerogatywy bractwa.

Pragnąc mianowicie zachęcić jego członków do modlitw za króla Zygmunta I, jego i swoich następców, za nienaruszalność i dobro Królestwa oraz za całe chrześcijaństwo, nadał im, jak również osobom obojga płci i z każdego stanu zapisanym do bractwa (dictis fratribus ac eis asscripticiis sexus utrin. sque et conditionis), prawo wyboru spośród członków bractwa spowiednika, który byłby uprawniony do odpuszczania grzechów zarezerwowanych dla ordynariusza. Z kolei urzędujący plebani, będący członkami bractwa, mogli sami lub przez swych wikarych czy innych zastępców rozgrzeszać swoich wyspowiadanych parafian obojga płci z wszystkich występków, z których rozgrzeszanie także było zarezerwowane dla ordynariusza, jak: potajemne podpalenia i zabójstwa, spędzanie płodów, publiczne swawole i zgorszenia, które normalnie wywołu ją skandale. W innych sprawach spowiednicy ci mieli zwracać się do ordynariusza lub penitencjarzy ustanowionych przez niego przy większych kościołach.

Bracia uzyskali prawo karania występnych członków bractwa, a innych, "buntowniczych i zuchwałych" mogli odesłać ordynariuszowi lub jego oficjałom do ukarania. Wtedy jednak ci „gorszyciele” mogli być potraktowani łagodnie i ukarani tylko upomnieniem.

Jeśliby członkom bractwa (fratribus et /lub sive/ confratribus) zarzucono jakiś występek wobec seniorów, obie strony mogły zgodzić się na sąd polubowny, złożony z członków bractwa. Gdyby jedna ze stron po uprzednim przyjęciu wyroku nie chciała się podporządkować temu orzeczeniu, wykonanie egzekucji miało należeć do władz kościelnych. Natomiast gdyby strona skazana nie chciała przy jąć wyroku starszych lub innych braci, strony obowiązane były udać się do właściwego sądu.

W przypadku konieczności wydania wiernym w sprawach sodalicji autentycznych dokumentów bractwa wraz z jego przywilejami i prerogatywami, bractwo to w obawie utraty swoich dokumentów miało prawo wydawać transumpty oryginałów, uwierzytelnione przez braci rektorów i pieczęć bracką, z mocą oryginałów.

W celu uwydatnienia charakteru sodalicji koprzywnickiej warto porów- 
nać ją z innymi tego typu korporacjami, np. z bractwem kapłańskim ziemi oświęcimskiej i zatorskiej, którego statut z 1378 r. i inne dokumenty opublikował Stanisław Kuraś34. Półtorawiekowy okres dzielący powstanie obu bractw rzuca dodatkowe światło na zagadnienia interesu jące założycieli tych konfraterni. Struktura obu tych wspólnot i obowiązki dewocyjne są podobne: dwóch rektorów, miejsce zebrań, w statucie oświęcimskim niesprecyzowane, zwoływanie na sesje za pomocą listów, nabożeństwa poprzedzające obrady oraz kazania do ludu, strój kapłanów w czasie obrad i nabożeństw - komża, stuła i świece, wykluczanie obcych podczas obrad, obowiązki wobec zmarłych członków bractwa, inne co do liczby modlitw i nabożeństw, ale zgodne co do istoty i trybu postępowania, traktowanie świeckich na nierównych prawach ${ }^{35}$. Także sposób odnoszenia się do „infamistów” wykazuje pewne analogie do trybu postępowania sodalicji koprzywnickiej z „buntownikami i zuchwalcami", określonego w 1539 r. przez biskupa krakowskiego Piotra Gamrata.

Nie ma natomiast w statucie koprzywnickim mowy o postanowieniach natury obyczajowej. Pomijając kary za nieobecność bez usprawiedliwienia na uroczystościach, naradach i ucztach brackich oraz spóźnianie się na nabożeństwa, w statucie bractwa kapłanów z księstw oświęcimskiego i zatorskiego znajdujemy wiele zakazów zabraniających konfratrom występowania podczas nabożeństw w ostrogach, otaczania się błaznami i włóczęgami, brania udziału w grach hazardowych, wstępowania do karczmy w dni zebrań brackich, zgorszenia. W statucie są też przepisy odnośnie do zachowania się przy stole podczas uczt. Brak w stucie koprzywnickim tego rodzaju postanowień, charakterystycznych dla bractw kelendowych w okresie kolonizacji na prawie niemieckim ${ }^{36}$, nie świadczy bynajmniej, że poziom moralny kleru w ciągu tych lat podniósł się na tyle od czasów kolonizacji, ażeby tego rodzaju przepisy były zbędne ${ }^{37}$. W pierwszej połowie XVI w. uwagę zwracano raczej na co innego.

34 S. Kuraś, Statuty i przywileje bractwa kapłańskiego dekanatu zatorskiego 1378-1525, „Polonia Sacra” 1955, nr 7, s. 253 i n.

35 Należy zaznaczyć, że rola świeckich w bractwie oświęcimsko-zatorskim wzrosła $\mathrm{z}$ czasem na tyle, że przepisy ustanowione dla niego przez ordynariusza w $1520 \mathrm{r}$. odnosza się już praktycznie do świeckich; ibidem, dokument nr 8.

36 Por. statut bractwa plebańskiego na Spiszu z 1298 r. - H. Ruciński, Prowincja saska na Spiszu do 1412 roku. (Na tle przemian spotecznych i ustrojowych $w$ komitacie spiskim i na obszarach przyległych), Białystok 1983, s. 197 i n.

37 Ks. J. Fijałek, Życie $i$ obyczaje kleru w Polsce średniowiecznej na tle ustawodawstwa synodalnego, Kraków 1997, wyd. II (na podstawie „Rozpraw Akademii Umiejętności Wydziału Historyczno-Filozoficznego", seria II, t. V, 1894). 
Wydaje się, że położenie nacisku, oprócz zawsze aktualnych obowiązków wobec zmarłych, na stronę organizacy jną bractwa miało na celu wzmocnienie dyscypliny kleru i silniejszą więź między sobą w obliczu nasilającej się reformacji.

Warto zwrócić uwagę na osobę notariusza publicznego Stanisława z Wiślicy ${ }^{38}$. Można przypuszczać, że jest to Stanisław z Wiślicy prepozyt koprzywnicki i pleban połaniecki (prepozyci koprzywniccy aż do drugiej połowy XVIII w. piastowali różne wysokie godności kościelne), współzałożyciel sodalicji. W ten sposób można by wytłumaczyć uzyskanie przez sodalicję 3 odpustów w ciągu zaledwie półtora roku. Cztery odpusty otrzymało bractwo w ciągu 5 dni lutego 1540 r., widocznie podczas jakiegoś zjazdu dostojników kościelnych w Krakowie, rozpoczętego być może już na przełomie listopada i grudnia 1539 r. (p. uzupełnienie statutu z 1 XII 1539 r.). Pod względem liczby nadanych w tak krótkim czesie indulgencji sodalicja kapłańska znacznie przewyższała inne bractwa koprzywnickie.

Koprzywnica nadawała się na siedzibę konfraterni kapłańskiej. Od 1185 r. istniał tam klasztor cysterski - Clara provincia. Oczywiście zakonnicy nie należeli do sodalicji ${ }^{39}$. Rozliczne jednak kontakty klasztoru $\mathrm{z}$ różnymi instytucjami kościelnymi mogły sprzyjać rozwojowi sodalicji. Była też Koprzywnica w pierwszej połowie XVI w. znaczącym ośrodkiem rzemieślniczym i handlowym. W miasteczku działały w tym czasie 4 cechy: kowalski (zaczątek przyszłego cechu zbiorowego), tkacko-krawiecki, farbiarski i garncarski. Odbywały się też 3 jarmarki rocznie. Wraz z rozwojem gospodarczym następował rozwój społeczny. Do chwili utworzenia sodalicji kapłańskiej egzystowały bractwa literackie (od 1430 r.) i ubogich (od 1496 r.). Zasadnicze znaczenie dla sodalicji kapłańskiej mogła mieć utworzona w $1491 \mathrm{r}$. przy kościele parafialnym Wszystkich Świętych w Koprzywnicy prepozytura i kolegium 5 mansjonarzy. Nieco wcześniej, przed 1473 r., powstał w miasteczku szpital z kościółkiem św. Ducha z osobnym prepozytem. Z powyższego wynika, że wybór Koprzywnicy na siedzibę sodalicji kapłańskiej był uzasadniony i rokował wszelkie szanse rozwoju. Niestety, po 1540 r. nie ma już żadnych wzmianek o sodalicji. Wiadomo tylko, że w 1700 r. jakiś nie

38 W jednym tylko wypadku, 2 V 1539 r., występuje Stanisław Simonis z Wiślicy, prawdopodobnie jednak jest to ten sam człowiek.

39 W ogóle nie ma śladów, aby w klasztorze koprzywnickim istniały jakiekolwiek bractwa. Brak również wzmianek źródłowych na temat przynależności mnichów koprzywnickich do jakichś bractw. 
zachowany do dziś przywilej sodalicji znajdował się w posiadaniu bractwa literackiego. Prawdopodobnie wynikiem zaniku sodalicji była nasilająca się reformacja ${ }^{40}$.

40 O sodalicjach kapłańskich w Polsce średniowiecznej pisali ponadto - B. Kumor, Statuty bractwa kapłańskiego oficjalatu pilzneńskiego przy kościele św. Jana Chrzciciela w Pilźnie, "Archiwa, Biblioteki i Muzea Kościelne”, t. 5, (1962), s. 385-392 oraz ks. W. Raczkowski, Konfraternie duchownych w wielkopolskiej części diecezji poznańskiej $w$ okresie przedtrydenckim ( $X V-X V I w$.$) , Lublin 1966, praca magisterska, maszynopis$ w Archiwum KUL (do tej pracy nie udało mi się dotrzeć). W Lublinie powstało w $1596 \mathrm{r}$. bractwo kapłańskie Bożego Ciała. Przed 1495 r. istniało w Lublinie bractwo (fraternitas magna sacerdotialis lublinensis) dla całego archidiakonatu lubelskiego - J. Flaga, Bractwa religijne $w$ archidiakonacie lubelskim do poczatku XVII wieku (1604), „Roczniki Humanistyczne" 1973, t. XXI, z. 2, s. 153, 155-156 i 165.

W 1450 r. biskup przemyski Piotr wydał konstytucję, w której są przepisy mające na celu podniesienie stanu moralnego niższego duchowieństwa, należącego do bractwa kapłańskiego w Przemyślu. Stowarzyszenia księży świeckich w diecezji włocławskiej poświadczone są źródłowo w 1568 r., za rządów biskupa Stanisława Karnkowskiego. Na Pomorzu Gdańskim (Prusy Królewskie), należącym do diecezji włocławskiej, takie bractwa prawdopodobnie wskutek reformacji uległy zanikowi, na co uskarżano się na synodzie dekanalnym w Gdańsku w 1585 r. - J. Fijałek, op. cit., s. 48.

W Europie Środkowej najbardziej znane było bractwo 24 plebanów spiskich - patrz H. Ruciński, Prowincja saska..., s. 183 i n. Ze względu na fakt, że Spisz graniczył z Małopolską i utrzymywał żywe kontakty z Krakowem i Nowym Sączem, jego oddziaływania na diecezję krakowską mogły być znaczne. Niemcy sascy przybyli na Spisz w drugiej połowie XII w. i zorganizowali tam własną prepozyturę, która w istocie była archidiakonatem, z tym że prepozyt spiski miał niektóre uprawnienia biskupie. W $1271 \mathrm{r}$. król węgierski Stefan V nadał Sasom spiskim obszerne przywileje, które stały się podstawą wykształcenia się prowincji saskiej na Spiszu. Za panowania Karola Roberta Andegaweńskiego prowincja ta obejmowała w 1317 r. 44 miejscowości. Z czasem jednak prawa Sasów spiskich uległy redukcji do 24 miast i osad królewskich. Wpływ na to ograniczenie terytorialne miało w pewnej mierze konstytuujące się w ciągu XIII w. bractwo 24 królewskich plebanów - por. K. Schwarz, Die Reformation in der Zips, w: Spišv kontinuite času, pod red. P. Śvorca, Prešov - Bratislava - Wien 1995, s. 49. Gdy w 1412 r. Zygmunt Luksemburski zastawił Władysławowi Jagielle część Spiszu, 13 spośród tych miast i osad przypadło Polsce i stanowiło starostwo spiskie, choć ich plebani nadal pozostawali pod jurysdykcja arcybiskupa ostrzyhomskiego. Oczywiście bractwa kapłańskie w Polsce nie stanowiły żadnego czynnika politycznego.

Swego czasu napisałem artykuł pt. Efemeryczna sodalicja kapłańska w Koprzywnicy (1534-1540) i wysłałem do wydawnictwa KUL. Po pewnym czasie otrzymałem artykuł do korekty i na początku stycznia 1985 r. odesłałem go do czasopisma "Summarium”. Od tego czasu słuch po artykule zaginął. Dopiero po ponownym napisaniu w nieco zmienionej formie dziejów tej sodalicji jako fragmentu niniejszego opracowania dr hab. Jerzy Flaga natknął się na wyżej wzmiankowany artykuł w „Summarium”, 11-12 (1982-1983), z odręcznym dopiskiem: „powielanie ukończono w kwietniu 1992” i przysłał mi jego kserokopię. Jak wynika $\mathrm{z}$ powyższego, numer jest antydatowany. 


\section{d. Bractwo św. Anny}

Zasadniczym źródłem do poznania tego bractwa jest oprócz akt powizytacyjnych księga wpisów tegoż bractwa pt. Volumen in numero fraternitatis s. Annae ecclasiae parochialis Coprivnicensis existentium inceptum Anno Domini 1686. Podobnie jak w księdze bractwa literackiego, księga bractwa św. Anny zawiera tylko daty wpisów, imiona, nazwiska i niekiedy miejscowość wpisanych, wyjątkowo inne szczegóły dotyczące przynależności stanowej lub zawodowej. Nie ma natomiast, poza dwoma wyjątkami, dat zgonów. Na osobnej, złożonej wpół karcie spisane są obowiązki religijne członków bractwa,-odpusty i forma przy jęcia do bractwa. Udało się ustalić, że autorem jej był ks. Franciszek Kuciński, wikary koprzywnicki wypełniający księgę bractwa literackiego od roku 1779 do początków XIX w., który wstąpił do bractwa św. Anny i został jego wicepromotorem w roku 1778.

Bractwo założył arcybiskup lwowski Jan Dymitr Solikowski, wielki orędownik i propagator tej konfraterni ${ }^{41}$. Potwierdzenia udzielił ordynariusz diecezji krakowskiej, kardynał Jerzy Radziwiłł 8 VII 1594 r. w Kielcach ${ }^{42}$.

Prawdopodobnie nie bez wpływu było założenie tegoż bractwa o rok wcześniej (9 VIII 1593 r.) w parafii św. Piotra w Sandomierzu. Z tej okazji otrzymało bractwo sandomierskie specjalną księgę bracką z kartą tytułową, drukowaną przedmową, informacją o wielkich zasługach bractwa pod kierunkiem bernardynów warszawskich ${ }^{43}$ i o korzyściach duchowych, które bractwo zapewniało. W przedmowie tej księgi, z podpisem i pieczęcią arcybiskupa Solikowskiego, pozostawiono puste miejsca na wpisanie miejscowości, kościoła parafialnego i kaplicy lub ołtarza, przy którym miało powstać bractwo. Po przedmowie następuje aprobata ordynariusza. Pozostałe karty są wolne, przeznaczone na wpisy i inne zapiski brackie ${ }^{44}$. Być może, że bractwo św. Anny w Koprzywnicy też posiadało taką księgę.

Bractwo to również przechodziło swoje wzloty i upadki. W roku 1646 w aktach wizytacji zanotowano, jak wspomniano, wiadomość o powstaniu bractwa św. Anny, a w roku 1676 zaznaczono, że istnieją bractwa literac-

41 Ks. B. Kumor, Kościelne stowarzyszenia..., s. 303 i 335-336.

42 AV, t. 7, (1646), s. 11.

43 Kościół św. Anny w Warszawie stał się centrum Archikonfraterni św. Anny. Inne bractwa były do niego agregowane - ks. B. Kumor, Kościelne stowarzyszenia..., s. 336.

44 Archiwum Diecezjalne w Sandomierzu, t. I-VIII, sygn. 23-25, 34-35, 132, 134 i 137. Nie jest to Societas s. Annae, Aviae Maternae Christi Szymona Hagenowa (patrz Encyklopedia kościelna, pod red. ks. M. Nowodworskiego, t. I, s. 258), lecz odrębna pozycja. 
kie i św. Anny bez żadnych fundacji, ale wykonujące swoje obowiązki religijne $\mathrm{z}$ pobożności ${ }^{45}$. Być może po wielkich zniszczeniach Koprzywnicy i zarazie $z$ lat pięćdziesiątych XVII w. zaistniały trudności w rewindykacji praw finansowych bractw. Pierwsze bowiem znane zapisy na rzecz bractwa św. Anny pochodzą, podobnie jak i dla bractwa literackiego, z początków XVII w., o czym niżej. Miało też bractwo swój ołtarz św. Anny w kościele parafialnym ${ }^{46}$. Wiadomość $\mathrm{z}$ akt wizytacyjnych $\mathrm{z}$ roku 1676 jest więc nieścisła. W roku 1686 bractwo założyło omówiony wyżej rejestr braci i sióstr, o którym wspomina wizytator w r. $1694^{47}$. Wydaje się, że do ożywienia działalności bractwa przyczynił się, podobnie jak to miało miejsce z bractwem literackim, prepozyt Stanisław Woycieski, który dwukrotnie, w roku 1694 i 1695 wpisywał się własnoręcznie do bractwa św. Anny. W każdym razie według wizytacji z r. 1694 bractwo oprócz rejestru miało swój przywilej i skrzynię. Co roku w dzień św. Anny (26 VII) odbywały się kongregacje, którym przewodniczył prepozyt lub z jego polecenia wikary. Na czele bractwa stało w tymże 1694 roku dwóch seniorów. Wydaje się jednak, że bractwo św. Anny miało mniej elitarny charakter od bractwa literackiego. Wiele osób, członków magistratu miejskiego, należało jednocześnie do obu bractw, pytanie jednak, czy pełnili w bractwie św. Anny funkcje kierownicze. Według zapisu wizytatora stali w roku 1694 na czele bractwa literackiego burmistrz Szymon Łopatkiewicz i rajca Jan Niewrzalski. Ten sam Jan Niewrzalski był jednocześnie seniorem bractwa św. Anny, ale został określony wraz z Jackiem Mądrym tylko jako civis. W 1671 roku był ławnikiem ${ }^{48}$, w roku 1692 wstąpił do bractwa św. Anny. Jako członek bractwa literackiego miał $\mathrm{z}$ tego bractwa wyderkauf ${ }^{49}$. Do wyższych godności miejskich zdaje się, nie doszedł. Należy jednak dodać, że inny znany nam członek władz bractwa św. Anny, podskarbi z r. 1742, zajmował wysokie godności w bractwie literackim, a w 1745 r. był burmistrzem ${ }^{50}$.

Niezbyt dokładna musiała być wizytacja bractwa w 1727 r., kiedy to stwierdzono, że bractwo św. Anny nie zostało erygowane i wprowadzone do

45 Visitationes externae et internae w Archiwum Diecezjalnym w Sandomierzu (dalej cyt. Vis.), t. 43 (1676), s. 9.

46 Podczas zarazy w roku 1653 Stanisław Spruch przed śmiercią zapisał $30 \mathrm{zł}$ na antypedium do bractwa św. Anny - Kodeks koprz., s. 5.

47 Vis., t. 44 (1694), s. 21.

48 Acta episcopalia, akta biskupie w Archiwum Kurii Metropolitalnej w Krakowie (cyt. dalej jako A.ep.), t. 77, s. 233v.

49 Ks. br. lit., s. 223.

50 Ibidem, s. 36. Pierwszy senior bractwa literackiego w r. 1746 - ibidem, s. 37. 
kościoła parafialnego oraz nie posiadało żadnego majątku, co, jak wiadomo, nie pokrywało się z prawdą. Być może zresztą, że $z$ funduszami nie było najlepiej, gdyż mieszczanie płacili wikarym 20 zł rocznie za cotygodniową mszę śpiewaną we wtorki (dzień poświęcony św. Annie) przy ołtarzu św. Anny ${ }^{51}$.

Kilkakrotnie, mianowicie w latach 1710,1721-1723 i 1731 bractwo zwało się archikonfraternią. Nie wiadomo, aby jakiekolwiek bractwo było agregowane do bractwa św. Anny w Koprzywnicy. Mogło tu chodzić albo o dodanie bractwu splendoru, albo o podkreślenie ściślejszych więzów, łączących wszystkie bractwa św. Anny na terenie Polski.

Sesje bractwa odbywały się $\mathrm{w}$ kościele parafialnym ${ }^{52}$ pod przewodnictwem prepozyta ${ }^{53}$ czy wikarego $=$ promotora lub wicepromotora $\mathrm{w}$ przypadku, gdy godność promotora rezerwowal dla siebie prepozyt ${ }^{54}$. Sesje odbywały się $\mathrm{z}$ reguły w święto patronki bractwa, to jest 26 lipca, choć były od tej zasady wy jątki.

W sumie w latach 1686-1795 do bractwa wstąpiło 1655 osób, w tym 1299 kobiet i zaledwie 356 mężczyzn, co stanowiło tylko $21,5 \%$ ogółu. W bractwie literackim kobiety również przeważały, przewaga ta jednak jest nieznaczna i wynosiła w latach 1694-1729 ponad 56\%. Wniosek stąd, że o ile kobiety w ogóle chętniej od mężczyzn zapisywały się do bractw, co miało, być może, związek z psychiką ludzką (zdaje się, że mężczyźni byli w swej masie bardziej indyferentni pod względem religijnym), to bractwa literackiego raczej unikały, może ze względu na zbyt duże wymagania intelektualne, a przynajmniej tradycję tych wymagań. Wiązało się to $\mathrm{z}$ brakiem wykształcenia $\mathrm{u}$ kobiet ${ }^{55}$. Może też bractwo literackie celowo ograniczało napływ kobiet, szczególnie uboższych.

Jedynym warunkiem wstąpienia do bractwa św. Anny był wiek umożliwiający przyjęcie komunii św. Dlatego też wśród wpisujących się spotykamy i szlachtę, i poddanych, dorosłych i młodzież, bogatych i biednych. Większość pochodziła spoza Koprzywnicy i to nieraz z miejscowości dość odległych, jak Sandomierz, Osiek, Dzików, a nawet Połaniec, Raków, Sienno, Ropczyce czy okolice Radomia. Zapisała się nawet w 1770 r. kobieta de $d u$ -

51 AV., t. 22 (1727), s. 129.

52 Est celebrata sessio in facie eccl. confraternitatis s. Annae - Ks. br. św. Anny, s. 24

531744 - ibidem, s. 31 .

54 Por. ks. F. Kuciński, op. cit., s. 18.

$55 \mathrm{Na}$ całym szeregu oświadczeń z XVIII w. o podjęciu sum z bractwa literackiego lub cechów koprzywnickich nie znalazł się ani jeden podpis kobiety, natomiast podpisy mężczyzn pojawiają się dosyć często. 
catu Saxoniae, niestety nazwisko nieczytelne. Stosunku koprzywniczan do osób spoza Koprzywnicy nie da się ściśle ustalić, gdyż często nie podawano miejsca pochodzenia kandydata. Część, poświadczonych przez inne źródła, dało się jednak zidentyfikować. Występuje też w księdze brackiej sporo nazwisk, co do których nie ma wątpliwości, że występowały wówczas w Koprzywnicy. Przypuszczalnie więc, wliczając w to duchownych z Koprzywnicy oraz osoby z Zarzecza, Owczarni, opactwa i Cegielni (osiedla wchodzące w skład aglomeracji koprzywnickiej), ilość członków z Koprzywnicy wynosiła około 750 osób, mniej więcej 45\%. Szlachty, tak z Koprzywnicy, jak i spoza niej, wstąpiło ogółem 80 osób, to jest niecałe $4,9 \%$. Z reguły była to szlachta biedna $z$ okolic Koprzywnicy. Niektórym z nich odmawiano nawet tytułów szlacheckich i tylko na podstawie innych danych można było ustalić, że zgłaszają oni pretensje do szlachectwa. Ponad tych szaraków wybijają się tylko Konstancja Słuszewska, podczaszanka żytomierska (1689) i magnificus ac generosus dominus Józef Dąbrowski, komisarz dóbr opactwa koprzywnickiego (1759). Duchownych niższych i wyższych święceń, tak z Koprzywnicy, jak i spoza niej, wystąpiło ogółem 18.

W porównaniu więc $\mathrm{z}$ bractwem literackim, w którym $3 / 4$ członków to mieszkańcy Koprzywnicy, bractwo św. Anny było bardziej otwarte dla osób przede wszystkim $z$ okolicznych wsi.

Największy rozkwit bractwa przypadł na pierwszą połowę XVIII w. W latach 1701-1752 aż 26 razy wstępowało do bractwa od 20 do 40 osób rocznie, a w r. 1726 - 75 osób. Kryzys nastąpił w ostatnich dziesięcioleciach tego wieku. Odbił się on wyraźnie na liczbie wpisów (wpisy od 1 do 5 rocznie wystąpiły 8 razy, z tej liczby 4 wypadki odnoszą się do lat osiemdziesiątych i dziewięćdziesiątych XVIII w. Wyjątek stanowi r. 1795, może pod wpływem nieszczęść, jakie dotknęły kraj i samą Koprzywnicę. Zapisało się w tym roku 15 osób, co było niespotykane od 10 lat.

Być może spadek popularności bract w drugiej połowie XVIII w. wiązał się z wpływami ideologii Oświecenia. Rozwiązanie tego problemu wymagałoby jednak pogłębionych studiów. Nie uległa natomiast osłabieniu działalność finansowa (legaty, kredyty) bractw i cechów w tym okresie.

Sposób przyjęcia do bractwa był następujący: wstępujący składał po polsku przysięgę: „Ja N przyjmuję bractwo Anny świętej, które w uczciwości i poszanowaniu mieć i jego powinności, ile czas pozwoli, wypełniać obiecuję i we wszystkim zadosyć czynić obowiązuję się temuż bractwu. Tak mi dopomóż Panie Boże w Trójcy Świętej jedyny i ty święta Anno", trzymając w ręku zapaloną świecę. Kapłan przyjmował go do bractwa, czyniąc go uczestnikiem odpustów nadanych bractwu przez papieży i życząc odpuszcze- 
nia grzechów oraz łask Bożych. Następowało błogosławieństwo i pokropienie wodą święconą ${ }^{56}$.

Na co dzień każdy członek bractwa powinien odmawiać 3 pacierze ( $3 \mathrm{~Pa}$ ter noster, 3 Ave Maria i 1 Credo) za dusze zmarłych braci i sióstr, a we wtorki koronkę do św. Anny (10 Pater noster, 30 Ave Maria i 1 Credo), przy czym informowano go, że w razie nieodmówienia wymienionych modlitw z powodu zapomnienia lub braku czasu nie grzeszy, lecz równocześnie pozbawia się zasług. Zasługą tą było przede wszystkim zapewnienie zbawienia, mianowicie odpust zupełny w chwili śmierci za wymówienie, a w razie słabości nawet pomyślenie imienia Jezus. Ponadto można było uzyskać dodatkowo szereg odpustów. Ci, którzy w dniu zapisywania się do bractwa spowiadali się i komunikowali, otrzymywali odpust zupełny nawet od grzechów zastrzeżonych wyłącznie dla papieża. Wynika stąd, że, przynajmniej teoretycznie, spowiedź i komunia nie obowiązywały przy wstępowaniu do bractwa. Odpust zupełny można było poza tym uzyskać przy każdej spowiedzi generalnej, przy spowiedzi i komunii w dzień św. Anny lub podczas procesji z Eucharystią oraz za nawrócenie innowiercy. Za nawiedzenie jakiegoś kościoła, przy którym istniało bractwo św. Anny, i zmówienie tam 5 pacierzy i pozdrowień anielskich oraz 1 Wierzę za wywyższenie Kościoła katolickiego, papieża i monarchy polskiego otrzymywało się, naturalnie będąc bez grzechu ciężkiego, odpusty rzymskie. Przepis ten świadczy o uniwersalizmie bractwa św. Anny. Za wysłuchanie mszy przy ołtarzu św. Anny raz na kwartał we wtorek oraz mszy żałobnej za zmarłych członków bractwa otrzymywało się 300 lat odpustu.

Jak widać, obowiązki nie były zbyt uciążliwe, a uzyskanie odpustów zależało od dobrej woli uczestnika. Nie wymagały też, może poza nawracaniem innowierców, żadnych większych kwalifikacji intelektualnych poza znajomością podstawowych modlitw. Powinności powyższe daleko odbiegają od ustaw bractwa św. Anny, zatwierdzonych przez nuncjusza papieskiego Jana Andrzeja Caligariego w r. 158157. Prawdopodobnie tak daleko idące złagodzenie uciążliwych ustaw Caligariego, w których znajdowały się przepisy nakazujące np. codzienną obecność na mszy św. - p. 2, noszenie znaku brackiego na szyi - p. 8, wykluczanie kobiet z sesji brackich - p. 10,

56 Luźna karta w księdze brackiej. Kapłan przyjmował do bractwa in nomine Sanctissimi Domini Nostri Summi Pontificis, to jest Chrystusa.

57 Nuncjusz Caligari wprowadzał w Polsce za panowania Stefana Batorego reformy soboru trydenckiego. O jego poczynaniach w odniesieniu do bractwa św. Anny - patrz Encyklopedia kościelna, pod red. ks. Michała Nowodworskiego, Warszawa 1873, t. II, s. 571. 
nastąpiło z czasem, z pewnością jednak niektórych punktów jego statutów nie przestrzegano od początku. Trudno sobie bowiem wyobrazić, żeby wiejski parobek czy koprzywnicka służąca studiowali naukę Kościoła, aby móc prowadzić dysputy teologiczne $z$ ludźmi innych wyznań ${ }^{58}$. Codzienna obecność na mszy też nie była możliwa nie tylko dla osób mieszkających poza Koprzywnica, ale i dla samych jej mieszkańców, z których duża część żyła głównie czy pobocznie $z$ rolnictwa. Zastąpiono więc udział w mszy modlitwami prywatnymi. O noszeniu specjalnych znaków (medalików) czy obowiązkowym płaceniu składek nic nie słychać, pijaństwo zaś zaczęło się właśnie szerzyć. Słynęli natomiast od wieków mieszkańcy Koprzywnicy z pieniactwa ${ }^{59}$. Udział w uroczystościach pogrzebowych zmarłych braci nie jest znany. Natomiast wybierało bractwo swoje władze, odbywało sesje, miało też swoją księgę i z pewnością skarbonę ${ }^{60}$.

Podstawę finansową bractwa stanowiły fundusze pochodzące $\mathrm{z}$ legatów i zbiórek, ziemia i rozmaite dary. W 1646 r. majątek bractwa musiał być znaczny, gdyż bractwo wspólnie $\mathrm{z}$ magistratem miejskim wyremontowało dzwonnicę kościelną ${ }^{61}$.

Wizytor stwierdził w r. 1676, że bractwa św. Anny i literackie nie mają żadnego majątku. W przypadku bractwa literackiego wiadomość ta okazała się jednak nieścisła.

W 1694 r. łącznie miało bractwo św. Anny około 300 zł, które przynosiły 22 zł i 16 gr czynszu. Praktyka lokowania pieniędzy była więc taka sama, jak w bractwie literackim.

$\mathrm{Z}$ tych dochodów między innymi opłacało bractwo organistę, dając mu 2 zł kwartalnie, bakałarza szkoły - 1 zł kwartalnie i dzwonnika, również 1 zł kwartalnie ${ }^{62}$. W 1727 r. bractwo podobno żadnego majątku nie miało, a na zapłacenie $20 \mathrm{zł}$ wikarym, którzy co tydzień we wtorek odprawiali mszę św. przed ołtarzem brackim, zbierano datki wśród mieszczan ${ }^{63}$. Za to wkrótce przybyły bractwu dwie role przy drodze sandomierskiej, jedna o powierzchni 3,5 staja, druga półłanowa ${ }^{64}$. W r. 1765 role te obsiewał prepozyt, widocz-

58 Punkty l i 5 - ibidem, s. 571; por. B. Kumor, Kościelne stowarzyszenia..., s. 336.

59 O zwalczaniu tych wad - Encyklopedia kościelna..., s. 571, p. 2, 4, 8 i 12 . O codziennym odmawianiu koronki lub 5 pacierzy - p. 15.

60 Ibidem, p. 9-11. O pogrzebach i mszach żałobnych - p. 13 i 14.

61 AV, t. 7 (1646), s. 10.

62 Vis., t. 44 (1694), s. 20.

63 AV, t. $22(1727)$, s. 129.

64 AV, t. 46 1748), s. 296. 
nie za odprawianie nabożeństw brackich. Miało wówczas bractwo trochę czynszów od mieszczan, ale wydatki swoje pokrywało głównie z jałmużny ${ }^{65}$. $\mathrm{Na}$ ołtarzu brackim znajdowało się trochę srebra, między innymi korony 66 . Do majątku brackiego należy ponadto zaliczyć chorągiew, z którą bractwo z pewnością występowało na procesjach ${ }^{67}$.

Podsumowując, bractwo św. Anny wysoko przekraczało swą liczebnością bractwo literackie. Prawdopodobnie członków przyciągała znaczna liczba odpustów. Bractwo literackie zaś zachowywało swój charakter elitarny i utrzymywało tradycję pewnego poziomu intelektualnego swych członków. Stąd dysproporcje co do miejsca zamieszkania członków bractw. W bractwie św. Anny znacznie większy odsetek stanowili członkowie spoza Koprzywnicy, choć znaczna część parafian należała jednocześnie do obu bractw. Mimo to bractwo św. Anny bardziej integrowało mieszczan z mieszkańcami okolicznych wsi oraz niwelowało, choć w niewielkim stopniu, przedziały stanowe ze względu na pewien odsetek braci pochodzenia szlacheckiego. Przygniatająca liczba kobiet (prawie 80\%) w bractwie św. Anny stwarzała im jakieś pole aktywności społecznej.

\section{e. Bractwo różań cowe}

Szerzone przez dminikanów już od końca XV w., bractwo różańcowe ${ }^{68}$ pojawiło się w Koprzywnicy stosunkowo późno.

Założycielem bractwa był cysters, o. Mateusz Gruszczyński, komendatariusz parafii koprzywnickiej i pierwszy jego promotor. Podstawy finansowe bractwa stworzył szlachcic z okolic Koprzywnicy, a zamieszkały w samym mieście, Wojciech Bolesta. On to 3 IX 1666 r. za zachętą i zgodą opata Zbigniewa Ossolińskiego i konwentu darował promotorowi łany Pęskowski i Peciowski, bez prawa sprzedaży tych łanów przez promotorów bractwa i z zastrzeżeniem dziesięciny snopowej i czynszów do klasztoru oraz podatków miejskich i państwowych. Patronem i kolatorem bractwa miał w przyszłości zostać prepozyt koprzywnicki o. Bernard Ważyński69. W 5 lat póź-

65 AV, t. 51 (1765), s. 224 i 224 v.

66 AV, t. 46 (1748), s. 422.

67 AV, t. 51 (1765), s. 229. Była to choragiew zielona z obrazem św. Anny.

68 E. Wiśniowski, Bractwa religijne na ziemiach polskich w średniowieczu, „Roczniki Humanistyczne" 1969, t. XVII, z. 2, s. 56.

69 Acta episcopalia, akta biskupie w Archiwum Kurii Metropolitalnej w Krakowie (cyt. dalej: A. ep.), t. 77 , s. 232-233v. 
niej, 19 X 1671 r. tenże Bolesta dołożył promotorowi bractwa jeszcze 2 obsiane role: Słowikowską i Nieczulską na polu Borki, odkupione niegdyś od prepozyta, dodając $90 \mathrm{zł} \mathrm{i} \mathrm{zastrzegając} \mathrm{tym} \mathrm{razem} \mathrm{dla} \mathrm{siebie} \mathrm{dożywotnie}$ kolatorstwo ${ }^{70}$ (darowizny stały się podstawą altarii różańcowej) ${ }^{71}$.

Bractwo musiało cieszyć się wielkim powodzeniem, gdyż altaria różańcowa została uposażona wieloma dotacjami, zamieniając się wkrótce w bogatą prebendę. W 1669 r. szlachetny Jakub Gorecki darował pole Kwaczyńskie $^{72}$. W 1682 r. wójt Jan Jasienicki sprzedał za 120 zł promotorowi bractwa pole mające 100 zagonów, należące do jego żony ${ }^{73}$, zaś w 1686 r. promotor otrzymał $70 \mathrm{zł} \mathrm{czynszu} \mathrm{rocznego} \mathrm{od} 1000 \mathrm{zl}$, które szlachetni Michał i Katarzyna Stradomscy zapisali Wojciechowi Boleście w r. 1682, a ten przeznaczył je dla promotora bractwa różańcowego. Testamentem oblatowanym w sądzie miejskim koprzywnickim w 1686 r. przekazał Bolesta tę sumę Józefowi Dunin Wąsowiczowi, skarbnikowi dobrzyńskiemu, a ten zapisał ją na swoich dobrach w Skrzypaczowicach $\mathrm{z}$ obowiązkiem płacenia czynszu rocznego prebendarzowi ${ }^{74}$.

Przy tak obfitym uposażeniu prepozyt szpitalny i dziekan koprzywnicki Szymon Woycieski pokusił się o zmianę altarii różańcowej na prebendę i wybudował przed 1694 r. kaplicę różańcową przy kościele parafialnym. Według opisu wizytatora wyglądała ona wówczas tak, jak dziś. Samo jej wyposażenie wynosiło $6000 \mathrm{zł}^{75}$. Wkrótce przybyły dalsze zapisy. W sumie prebenda w 1714 r. miała 10090 zł przynoszących 610 zł rocznego dochodu, nie licząc obfitego uposażenia w ziemię.

20 II 1715 r. w Kielcach ordynariusz zatwierdził prebendę różańcową pod wezwaniem NMP w Koprzywnicy i wydał dla niej statut. Prebenda została wyodrębniona prawnie od kościołów parafialnego i szpitalnego. Zatwierdził też biskup bractwo różańcowe, od dawna istniejące, ale nie erygowane kanonicznie. Prebendarz miał obowiązek odprawiania dwóch mszy tygodniowo - w poniedziałki za fundatora ks. Szymona Woycieskiego i w piątki za dusze w czyśćcu cierpiące, a w niedzielę śpiewać różaniec sam lub przez innego kapłana, natomiast bez prawa wyręczania się organistą lub kanto-

70 Ibidem, s. $233 \mathrm{v}-235$.

71 Vis., t. 43 (1767), s. 9. Tamże zamiast łanu Pęskowskiego występuje łan Cyrkowski.

72 Vis., t. 43 (1767), s. 9.

73 A. ep., t. 77 , s. 229.

74 Ibidem, s. 230v-232. W Sandomierskiem wiele ze szlachty wywodziło swe pochodzenie od legendarnego Dunina.

75 Vis., t. 44 (1694), s. 21-22. 
rem czy innym świeckim. W każdą pierwszą niedzielę miesiąca prebendarz miał śpiewać mszę wotywną De Beata za żywych i zmarłych członków bractwa, z dodaniem kolekty, wraz $\mathrm{z}$ obowiązkiem opłacania organisty i kantora. Czas i miejsce tych nabożeństw miał uzgodnić z prepozytem, aby nie przeszkadzać normalnemu kursowi nabożeństw parafialnych. Winien był posłuszeństwo prepozytowi i miał mu pomagać, słuchając spowiedzi w okresie wielkanocnym oraz biorąc udział w procesjach i nieszporach. Prebenda miała mieć oddzielny spis inwentarza, a prebendarz miał obowiązek zaopatrywać kaplicę w wino i wszystko, co potrzebne. Prawo patronatu, którym fundator ks. Szymon Woycieski obdarzył swego bratanka Stanisława, przeszło na egzekutorów testamentu tego ostatniego, a następnie na kapitułę sandomierską i starostę klucza biskupiego w Złotej, zgodnie $\mathrm{z}$ wolą fundatorów. Na koniec zastrzegł biskup, że miejscowym duchownym: prepozytom parafialnemu i szpitalnemu oraz wikarym, nie wolno obejmować tej prebendy ${ }^{76}$. Jednak zasada ta ze względu na bogate uposażenie prebendy została wkrótce złamana. Już prepozyt koprzywnicki, kanonik sandomierski i mistrz ceremonii biskupów krakowskich, Jan Salepeciński, wszedł w posiadanie prebendy, a po jego śmierci w 1722 r. prebendarzem został ks. Cyprian Langi dr obojga praw i kanonik wiślicki ${ }^{77}$, późniejszy prepozyt koprzywnicki.

Jak więc widać, bractwo różańcowe, mimo powierzchownych pozorów, miało zupełnie inny charakter od poprzednich. Istniało ono przy bogatej prebendzie, obsadzanej przez osoby piastujące wysokie godności kościelne. W 1694 r. stwierdzono, że bractwo odbywa kongregacje generalne w dzień Narodzenia NMP (8 IX). Nie był to jednak termin stały, gdyż w następnym roku odłożono kongregację do pierwszej niedzieli października. Seniorów wybrano podczas kongregacji, lecz do czasów wizytacji już ich nie było. Miało bractwo skrzynię, przywilej oraz spis braci i sióstr, nie miało natomiast żadnego funduszu, a wino i wosk kupowali bracia wyłącznie z jałmużny ${ }^{78}$.

76 A. ep., t. 77, s. $235-236 \mathrm{v}$.

77 A. ep., t. 78 , s. $142 \mathrm{v}$.

78 Vis., t. 44 (1694), s. 21 - Seniores eiusdem confraternitatis ad praesens non sunt, qui annis praeteritis eligebuntur pro festo Nativitatis $B M V$ in congregatione generali. Nie wiadomo też o jaki przywilej może chodzić, gdyż biskup w 1715 r. o takowym nie słyszał. Nie było to zresztą potrzebne, gdyż papież Innocenty XI w 1679 r. potwierdził wszystkie istniejące wówczas bractwa różańcowe i uznał je za prawne nawet, gdyby nie można było dowieść erekcji - Podręczna encyklopedia kościelna, pod red. ks. Zygmunta Chełrnickiego, Warszawa 1905, t. V-VI, s. 120. 
W 1727 r. bractwo różańcowe miało „chorągiew wielką różańcową, adamaszkową" oraz obraz do noszenia w procesjach, album cofraternitatis, czyli rejestr członków, który się niestety nie zachował, i książkę do śpiewania różańca. Ponadto posiadało skarbonę $\mathrm{z}$ dwoma zamkami i „stolik mały bracki na szchadzki", przy którym zapewne zasiadał promotor ze starszymi ${ }^{79}$. W tym też roku zostało ono wprowadzone i inkorporowane do kaplicy różańcowej przez prebendarza Cypriana Langiego. W 1748 r. bractwo miało 2 księgi: jedną dużą „do wpisowania officjalistów rozancowych na schadzkach" i drugą małą, podłużną „do wpisowania w Rożaniec" 80 .

Ze znanych obowiązków członków bractwa różańcowego można wymienić tylko jeden - śpiewanie wraz z prebendarzem w każdą niedzielę i święto różańca ${ }^{81}$.

Wszelkie legaty do kaplicy różańcowej odbierał prebendarz ${ }^{82}$, bractwo zaś nie miało żadnego majątku, nie licząc skarbony, ksiąg, chorągwi itp. Jałmużny i dochód ze skarbony przeznaczało prawdopodobnie na zakup tego rodzaju utensyliów oraz na świece, które bracia mogli nieść na procesjach. Decydującą rolę odgrywał prebendarz, będący zarazem promotorem bractwa. Rola starszyzny brackiej była prawdopodobnie znikoma i ograniczała się do działalności typu porządkowego i reprezentacyjnego. Wątpliwe, czy bractwo, pozbawione majątku, miało osobowość prawną. Nic dziwnego, że nigdy nie było ono nazywane, tak jak inne bractwa i cechy, terminem communitas.

Przynależność do tego bractwa (według opinii księży Stanisława Puławskiego i Jana Wiącka, proboszczów koprzywnickich, miało być ono najliczniejsze) wynikała zapewne $\mathrm{z}$ pobudek czysto dewocyjnych. W niektórych wypadkach udało się ustalić, że należeli do tego bractwa członkowie bractw literackiego i św. Anny.

Statuty średniowieczne kładły duży nacisk na obowiązki pogrzebowe bractw. W późniejszych źródłach koprzywnickich niewiele się o tym mówi (między innymi istniał obowiązek towarzyszenia kapłanowi udającemu się do chorego $\mathrm{z}$ wiatykiem). $\mathrm{Z}$ pewnością jednak te obowiązki były wykonywane.

79 AV, t. 22 (1727), s. 434.

80 AV, t. 46 (1748), s. 302.

81 AV, t. 51 (1765), s. 231.

82 Oświadczenie Łukasza i Reginy Olbratowiczów z r. 1776 o przejęciu wraz z nabytymi gruntami 100 zł „do ołtarza NP Różańcowej to jest do kaplicy różańcowej” z prowizja $5 \mathrm{z}$, z zastrzeżeniem, że prebendarz musi od nich w każdej chwili tę sumę odebrać - archiwum parafialne w Koprzywnicy. 
Wiadomo, że około 1724 r. wikariusze z bractwem (jakim?) z chorągwiami musieli odprowadzić do kościoła klasztornego zwłoki niejakiego Ryzewicza, którego pochowano w klasztorze ${ }^{83}$. W r. 1765 wizytator zapisał w inwentarzu kościelnym 36 kap brackich grubych ${ }^{84}$, które mogły być używane na procesjach i pogrzebach.

Innym ogólnym objawem jest rozszerzający się od XVII w. kult MB Częstochowskiej. Już w 1653 r. rajca Tomasz Chranowski zapisał w testamencie pewną sumę do klasztoru jasnogórskiego ${ }^{85}$. W sto lat później na wszystkich ołtarzach brackich i cechowych w kościele farnym w Koprzywnicy znajdowały się obrazy MB Częstochowskiej ${ }^{86}$.

\section{Bractwa cechowe}

Na temat genezy cechów istnieją ciągle poważne rozbieżności. Stanowiska odnoszące się do tego zagadnienia (Brentano, Wilda, Coornaet, Kuliszer, Małowist) przedstawia ks. Bolesław Kumor, przychylając się w zasadzie do tezy o religijnej genezie cechów ${ }^{87}$. Maurycy Horn powstanie cechów tłumaczy wyłącznie rozwojem sił wytwórczych, pogłębianiem się dyferencjacji rzemiosła i liczebnym wzrostem rzemieślników ${ }^{88}$, obowiązki religijne cechów natomiast zupełnie pomija. Stanisław Herbst sprawom religijnym w cechach poświęca niewielki fragment, zwracając uwagę na zapożyczenia ceremoniału cechowego $\mathrm{z}$ liturgii kościelnej lub z życia rycerskiego w celu dodania blasku trywialnej codzienności. Pierwsze fundacje i bractwa religijne pojawiły się w Toruniu około 1400 r., a więc znacznie później niż cechy. Zasadniczym celem tych fundacji były usługi pogrzebowe. Za odpowiednią opłatą mogły $\mathrm{z}$ tych usług korzystać również osoby spoza cechu.

83 Ks. S. Puławski, Notatki, f. 56. Znajdują się one w Bibliotece Seminarium Duchownego, sygn. J $1131 \mathrm{~b}$.

84 AV, t. 51 (1765), s. 229. Nie wiadomo, o jakie bractwo chodzi.

85 Kodeks koprz., s. 41.

86 AV, t. 51 (1765), s. 229.

87 B. Kumor, Kościelne stowarzyszenia..., s. 307. Stanisław Chodyński stwierdza wprost, że z bractw powstały niektóre zakony i cechy (contubernia) - Bractwa, w: Encyklopedia kościelna..., t. II, s. 552.

88 M. Horn, Rzemiosto miejskie województwa betzkiego w pierwszej potowie XVII wieku. Zagadnienie kryzysu gospodarczego Rzeczypospolitej szlacheckiej w XVII wieku, Wrocław 1966, s. 255; K. Arłamowski, Dzieje przemyskich cechów rzemieslniczych w dawnej Polsce, Przemyśl 1931, s. 244. 
Powstały też tak zwane „cechy śmiertelne”, jednoczące przeważnie różne cechy ${ }^{89}$. Henryk Samsonowicz upatruje genezę cechów w strukturze gospodarczej średniowiecza. Przy bardzo wąskim kręgu odbiorców w związku z gospodarką naturalną wsi rzemieśnicy dążyli do monopolizacji różnych gałęzi wytwórczości. Autor zwraca jednak uwagę na wpływ kultu świętych dla zachowania odrębności cechowej i na formy działania starszyzny cechowej ${ }^{90}$. Wydaje się (sprawa wymaga pogłębionych badań porównawczych), że między bractwami na terenie Niemiec oraz północnych i zachodnich obszarach Polski; opanowanych w poważnej mierze, zwłaszcza w miastach, przez element niemiecki, a bractwami religijnymi w Koronie były dość istotne różnice. Badający zagadnienia bractw na Pomorzu Zachodnim Helmuth Heyden, w pewnym sensie utożsamia bractwa $z$ cechami. Genezę tych stowarzyszeń (die Berufgenossenschaft, die Gilde, die Zunft) powstałych przy współudziale władz miejskich upatruje on w dążeniu jednostek do zapewnienia sobie opieki, jak również w wysokim poziomie rzemiosł wykluczającym partaczy i wyeliminowaniu współzawodnictwa między rzemieślnikami. Przywileje cechowe zapewniały samorządność i własne sądownictwo, stwarzały wzorce moralnego postępowania oraz określały zachowania się w gospodach cechowych (das Gildenhaus). Najbardziej istotnym rysem działalności cechów były jednak ich funkcje religijne, jak wspólne nabożeństwa we własnych kaplicach czy przy własnych ołtarzach, pogrzeby czy aniwersarze. Wszelkie ważniejsze uroczystości kościelne bractw - cechów kończyły się wspólną ucztą w domu brackim. Za opiekę nad kościołami i wspomaganie ubogich bractwa otrzymywały odpusty ${ }^{91}$. Według Georga Materna istotnymi cechami bractwa (die Bruderschaft) były władze (dwóch starszych), ołtarze, latarnie, wigilie i aniwersarze, Morgensprache i piwo brackie $^{92}$. Cele więc religijne $\mathrm{i}$ towarzyskie były tu identyczne jak w cechach. Nic dziwnego, że zajmujący się dziejami miast hanzeatyckich Stanisław Herbs i Henryk Samsonowicz nie zwrócili w swych opracowaniach większej uwagi na bractwa religijne. W Królestwie Polskim natomiast statuty brackie były autoryzowane przez ordynariuszy i ograniczały się wyłącznie do wymienienia obowiązków religijnych członków i odpustów, zaś wszelkiego

89 S. Herbst, Toruńskie cechy rzemieślnicze. Zarys przeszłości, Toruń 1933, s. 43-44.

90 H. Samsonowicz, Życie miasta średniowiecznego, Warszawa 1970, s. 74-76.

91 H. Heyden, Kirchengeschite Pommerns, t. I, Von den Anfängen des Christentums bis zur Reformationszeit, wyd. II, Köln - Braunsfeld 1957, s. 159 - Ein wesentliches Merkmal (der Gilden) aber war die religiöse und kirchliche Betätigung.

92 G. Matern, op. cit., s. 18. 
rodzaju uczty i poczęstunki, a nawet rozmowy nie związane $\mathrm{z}$ działalnością religijną bractwa były przez władze kościelne energicznie zwalczane ${ }^{93}$. Różnica więc między bractwem a cechem była na terenie Polski bardzo wyraźna.

Na społeczno-kulturalny aspekt zagadnienia zwrócił uwagę Jerzy Kłoczowski. Już od XI-XII w. mamy do czynienia z organizowaniem się ludzi wyrywających się na stałe lub czasowo $z$ więzów zależności feudalnej. W tym też czasie zaczęły pojawiać się komuny miejskie, których członkowie pod przysięga zobowiązywali się do walki o swe prawa. Wystąpiły też objawy dążeń o dowartościowanie ludzi świeckich. Nasiliły się te procesy w XIV-XV w., gdy ujawnił się rozkład starych wzorców społecznych typu senioralno-feudalnego oraz więzów łączących w gminach miejskich. Wystąpiło w masach zapotrzebowanie na nowe wzorce wspólnego życia religijnego, a wartości religijne stały się czynnikami integrującymi poszczególne grupy ludzi ${ }^{94}$.

Wydaje się, że na powstanie cechów złożyło się wiele z tych czynników. Odpowiedni poziom sił wytwórczych był tu niezbędny, zważywszy że były to organizacje oparte na podstawach gospodarczych. Jednak dominująca w psychice ówczesnych ludzi obawa przed śmiercią, zwłaszcza w okresie narastania kryzysu feudalnego i wielkich epidemii z „czarną śmiercią” na czele oraz nowe prądy ideologiczne, kazały szukać wzorców organizacy jnych w Kościele, tym bardziej że grupy rzemieślnicze nie zdołały jeszcze wypracować własnych wzorców.

W XV w. na ziemiach polskich powstało szereg organizacji zwących się cechami rzemieślniczymi, ale erygowanymi przez biskupów, a zakres ich obowiązków i statuty w niczym istotnym nie różniły się od bractw religijnych sensu stricto. Mogły też one przyjmować w swe szeregi osoby płci obojga, które z wykonywaniem zawodu wyszczególnionego w tytule cechu nie miały nic wspólnego. Oczywiście trzon takiego „cechu” musieli stanowić rzemieśl-

93 Na przykład Statut Bractwa Literackiego Nauki Chrześcijańskiej w Nowym Saczu wydany przez ks. B. Kumora (Statuty Bractwa Literackiego...). Przykłady tego rodzaju statutów brackich można znaleźć w wydawnictwie S. Kurasia, Zbiór dokumentów katė$d r y . . .$, cz. I, Lublin 1965, cz. II (1416-1450), Lublin 1973. W archiwach kieleckim i radomskim znalazłem dane, że w XIX w. istniał w Koprzywnicy cech włościański. Ponieważ zagadnienie to wykracza poza ramy chronologiczne niniejszego opracowania, nie zajmowałem się nim, tym bardziej że dane na temat tego bractwa są bardzo skąpe.

94 J. Kłoczowski, Wspólnoty chrześcijańskie. Grupy życia wspólnego w chrześcijaństwie zachodnim od starożytności do XV wieku, Kraków 1964, s. 195-196 i 458-459. Autor podkreśla, że procesy te są $\mathrm{w}$ historiografii mało zbadane. 
nicy danej specjalności, gdyż inaczej nazwa tego rodzaju organizacji nıe miałaby żadnego uzasadnienia ${ }^{95}$.

Nie jest dotąd zbadana relacja między bractwami cechowymi a cechami. Szególnie ciekawe wyniki mogłoby przynieść zbadanie w każdym konkretnym wypadku, co jest wcześniejsze - bractwo cechowe czy cech i czy każde bractwo cechowe miało swój odpowiednik w cechu posiadającym statut regulujący życie gospodarcze cechu. Rzuciłoby to nowe światło na genezę cechów i bractw, a w pewnym stopniu wyjaśniłoby zagadnienie, skąd czerpały one wzory organizacyjne.

Na terenie Koprzywnicy w drugiej połowie XV w. powstało bractwo cechowe tkaczy i krawców. 13 IX 1484 r. w Koprzywnicy biskup przemyski Jan Kazimirski za zgodą ordynariusza diecezji nadał odpust wyspowiadanym i skruszonym braciom bractwa sztuki tkackiej i krawieckiej w mieście Koprzywnicy, aby ludzie płci obojga korzystali w tychże bractwach $\mathrm{z}$ większych lask duchowych i miłosierdzia za udział $\mathrm{w}$ modłach, nabożeństwach i pielgrzymkach oraz za dary dla kościoła parafialnego w postaci paramentów, ksiąg, wosku czy ofiar na fabrykę kościoła ${ }^{96}$. O cechu

95 Szczegółowiej tego rodzaju cechy omawia E. Wiśniowski, op. cit., s. 60-62. Autor nazywa tego rodzaju organizacje bractwami cechowymi. M. Horn używa terminu „bractwo cechowe" na oznaczenie cechu (tenże, Lokalizacja cechów i specjalności rzemieślniczych $w$ miastach ziemi przemyskiej i sanockiej w latach 1550-1650, „Przegl. Hist.” 1970, t. 61, z. 3, passim), choć wspomina o odpustach nadanych cechom przez biskupów - ibidem, s. 416, przyp. 133. Szewcy przemyscy odwrotnie - wpierw otrzymali przywileje gospodarcze od starosty ruskiego (1386), a póżniej odpusty od biskupa Piotra Kościeszy (1437) - K. Arłamowski, op. cit., s. 11 i 226 . W Przemyślu istniała też kategoria tak zwanych braci cechowych lub przystępniów, którzy po złożeniu pewnych opłat uczestniczyli w uroczystościach kościelnych cechu, a cech asystował przy ich pogrzebach. W cechu piekarskim otrzymywali oni ponadto prawo wypieku pewnych gatunków pieczywa - ibidem, s. 105 i 226.

96 Dokument w Archiwum Diecezjalnym w Sandomierzu, bardzo zniszczony, stąd niemożliwy do odczytania w całości - fratres fraternitatis sub titulo artis textorie, sartorie (...) in oppido Coprzyvnicensi. Nie wiadomo, czy do tego bractwa należały jeszcze inne cechy. Ciekawym jest, że w dalszym ciągu mowa raz o bractwach (in ipsis fraternitatibus), a innym razem o bractwie (ad eandem fraternitatem quomodolibet ascriptis). Może więc tkacze i krawcy mieli osobne bractwa, albo obok wspólnego bractwa tkaczy i krawców było jeszcze inne tego typu bractwo wymienione w zniszczonych częściach dokumentu. Liczba dni odpustu niemożliwa do odczytania. Ogólna praktyka przewidywała wówczas 40 dni.

Formularz, w oparciu o który powstał powyższy przywilej, powtarza się dla bractw cechowych w innych miejscowościach. Pojawia się on już w 1404 r. dla bractwa w kaplicy św. Barbary przy kościele mariackim w Krakowie. H. Zaremska, op. cit., s. 45 i 175. Liczne przykłady dokumentów na podstawie tego formularza patrz: Zbiór dokumentów katedry...; H. Ruciński, Cechy rzemieślnicze..., s. 103.

„Fabryka kościoła” to kwestia utrzymania budynku kościelnego i jego wyposażenia. Było to w gestii witryków. 
tkackim w Koprzywnicy słychać dopiero w 1564 r., a o cechu krawieckim w 1727 r. ${ }^{97}$

Innym bractwem cechowym na terenie Koprzywnicy było istniejące w drugiej połowie XVIII w. bractwo cechu kowalskiego MB Loretańskiej i śś. apostołów Piotra i Pawła. Byli w cechu kowalskim suchedniarze, czyli rzemieślnicy robiący na własną rękę, lecz nie spłaceni jeszcze na majstrów, którzy obowiązani byli co kwartał płacić do lady jeden zł na Suche dni ${ }^{98}$. Czy tylko oni należeli do bractwa? Raczej w jego skład wchodzili wszyscy rzemieślnicy kowalscy i inni należący do cechu zbiorowego, a suchedniarze mogli w nim stanowić pewną grupę. Suchedniowe było uzależnione od woli wpisującego się. Niejaki Walenty Świstak z żoną, przyjmując bractwo w 1764 r., zobowiązał się płacić suchedniowe w wysokości 1 zł 2 gr ${ }^{99}$. Natomiast obligacja suchedniowego małżonków Walentego i Jadwigi Pietraszkiewiczów nie jest znana z powodu uszkodzenia tekstu. Wynika więc, że do bractwa małżonkowie wstępowali razem. Do władz bractwa należały również kobiety. W 1799 r. seniorką bractwa była Salomea Pastrowska, „seniorka cechu kowalskiego biorąca świce po śmierci meza swego do tych czasów".

Według danych z XVIII w. cechy, bractwa oraz rzemiosła opiekowały się następującymi ołtarzami $\mathrm{w}$ kościele parafialnym:

1. Ołtarz wielki pw. Wszystkich Świętych - szewcy $(1748,1765)$.

2. Ołtarz Zwiastowania NMP - garbarze (1748) i kuśnierze (1765, 1779, 1796).

W 1794 r. kuśnierze mieliby opiekować się ołtarzem Niepokalanego Poczęcia NMP. Prawdopodobnie nastąpiła pomyłka nazwy ołtarza.

3. Ołtarz św. Józefa - po bractwie ubogich (1748) tkacze (1765).

4. Ołtarz św. Sebastiana - krawcy $(1727,1748,1765)$.

5. Ołtarz NMP Loretańskiej - kowale i inni rzemieślnicy (1727, 1748, $1765)$.

97 H. Ruciński, Cechy rzemieślnicze..., s. 104.

98 Słownik języka polskiego Jana Karłowicza, Adama Kryńskiego i Władysława Niedźwieckiego, Warszawa 1915, t. VI, s. 501. Lada - szkatuła, kasa cechowa, mieszcząca skarbiec cechu rzemieślniczego - ibidem, t. II, s. 673.

99 Skądinąd wiadomo, że Walenty Świstak był człowiekiem zamożnym. Pożyczył on niejakim Kitlińskim 288 zł, które w r. 1787 legował do bractw i cechów - Ks. br. lit., s. 219. 
Od r. 1790 krawcy opiekowali się ołtarzem św. Barbary. Prawdopodobnie nastąpiła zmiana nazwy ołtarza, w związku z czym cech zmienił patrona ${ }^{100}$.

W statutach cechowych występu ją różne kary i opłaty w wosku. Oczywiście wosk ten był potrzebny do wyrobu świec na potrzeby ołtarza lub przy procesjach ${ }^{101}$. Statut cechu kuśnierzy koprzywnickich zobowiązywał ich ponadto, żeby pieniądze ze skrzynki brackiej obracać na pożytek i ozdobę swego ołtarza. Natomiast na schadzkach cechu zbiorowego miano radzić nad pomnożeniem chwały Bożej i pożytkami cechu. Mistrzowie i czeladnicy cechu zbiorowego mieli obowiązek uczestniczyć w każde Suche dni w mszach i nabożeństwach za dusze zmarły.ch, aż do ich zakończenia, w przyzwoitym ubraniu, nie w tym, które noszą w warsztacie, pod karą 1 grosza. Podobnie 1 gr mieli płacić ci, którzy nie uczestniczyliby lub nie chcieli usługiwać w nabożeństwach za zmarłych. Wreszcie za nieobecność na procesji w Boże Ciało i podczas jego oktawy groziła kara pół grosza. Cech kuśnierski nakładał na swych członków obowiązek uczestnictwa w mszach, nieszporach i procesjach przez całą oktawę Bożego Ciała pod karą 1 gr za każde zaniedbanie. Mistrzowie cechu płócienniczego za nieobecność lub zatrzymanie znaku cechowego, zwołu jącego na kondukty, wigilie i pogrzeby, płacili 2 funty wosku ${ }^{102}$.

Ołtarzami cechowymi opiekowali się młodsi mistrzowie. W cechu zbiorowym tzw. brat młodszy, wybrany i ustanowiony, musiał w niedziele i święta na obu nieszporach, jutrzniach, modlitwach, mszach, ofertoriach i kompletach zapalać i gasić świece pod karą 2 groszy. W wypadku, gdyby chciał się zrzec tych obowiązków musiał zapłacić 4 grosze. W cechu kuśnierskim każdy nowo przy jęty mistrz pełnił obowiązki młodszego brata, kiedy zaś opuszczał ten urząd składał 6 funtów wosku ${ }^{103}$. W cechu płócienniczym natomiast czterech młodszych mistrzów w Boże Ciało i oktawę musiało wraz z „wach-

100 AV, t. 22 (1727), s. 126; AV, t. 48 (1748), s. 227; AV, t. 51 (1765), s. 223v; oświadczenia luźne w archiwum parafialnym w Koprzywnicy: Dziubkowej dla cechu kuśnierskiego - 1779; Niedźwieckich dla cechu krawieckiego - 1790; Grudniowskich i sukcesorów Janczaczki dla cechu kuśnierskiego - 1794 i 1796.

Poza wymienionymi istniały $w$ kościele parafialnym $w$ Koprzywnicy ołtarze św. Anny (bractwo św. Anny), Wniebowzięcia NMP (bractwo literackie) i NMP Różańcowej (prebendarz i bractwo różańcowe).

101 Sex libras cerae ad usum ecclesiae parochialis reponere - cech zbiorowy 1603 ; „Kamień wosku na ozdobę cechową" - Tkacze 1748, p. 15.

102 Tkacze 1784, p. 13.

103 Cech zbiorowy 1603 i Kuśnierze 1689. 
tami" uczestniczyć we wszystkich nabożeństwach oraz rozdawać świece pod karą 1 gr od każdej nie wydanej świecy ${ }^{104}$.

Oprócz opłat i składek przewidzianych statutami fundusze cechowe powiększały różne legaty do ołtarzy cechowych, z obowiązkiem odprawiania określonych ilości mszy za dusze legatorów. Cechy, podobnie jak bractwa, pragnąc zadośćuczynić tym zobowiązaniom wypożyczały legowane sumy na wyderkauf, a z procentów opłacały kapłana odprawiającego msze.

O legatach i działalności kredytowej cechów zachowało się niewiele wiadomości. Najwięcej z nich odnosi się do cechu kuśnierskiego, co nie jest chyba przypadkiem, zważywszy, że cech ten wyróżniał się wśród pozostałych cechów i bractw wielkością posiadanych kapitałów ${ }^{105}$.

W roku 1779 niejaka Katarzyna Pietruszczyna z Koprzywnicy legowała do ołtarza cechu kuśnierskiego jedną staję (10 zagonów i 2 kliny) roli wartości 100 zł. Rolę tą przekazała swojej córce jedynaczce Jadwidze Dzióbkowej z obowiązkiem wypłacania czynszu 6 zł rocznie na św. Katarzynę (25 XI), na mszę w ten dzień za duszę legatorki. Gdyby Jadwiga nie wywiązała się ze swych obowiązków, cech mógł jej wymienioną rolę odebrać, miała ona jednak prawo pierwokupu. W 2 lata później cech zmniejszył Jadwidze czynsz do $5 \mathrm{zł}$. W roku 1795 Agnieszka Janczaczka legowała do cechu kuśnierskiego 100 zł, które przejęli jej sukcesorowie z obowiązkiem wypłaty czynszu rocznego na 15 marca w wysokości 5 zł, z czego 2 zł na mszę za dusze legatorki i jej męża w Dzień Zwiastowania NMP (25 III), a 2 zł „na oporządzenie tegoż ołtarza lub na wosk Łuy (łój) opalając". W r. 1788 wzięli z cechu

104 Tkacze 1784, p. 9. Wachty to grupy adoratorów.

$105 \mathrm{Wg}$ protokołu $\mathrm{z}$ roku 1838 :

bractwo św. Anny miało dłużników - 13, czynszu $\quad-75$ zł 6 gr

bractwo literackie $\quad-13, \quad-55 \mathrm{zł} 6 \mathrm{gr}$

cech kowalski $\quad-\quad 9, \quad-46 \mathrm{zł} 9 \mathrm{gr}$

cech krawiecki - 6, $\quad-22$ zł 15 gr

cech kuśnierski $\quad-\quad 17, \quad-94 \mathrm{zł} 3 \mathrm{gr}$

cech szewski $\quad-12, \quad-63 \mathrm{zł} 15 \mathrm{gr}$

cech płócienniczy $\quad-\quad 12, \quad-61 \mathrm{zł}$

Proboszczowi i organiście za nabożeństwa płaciły ww. bractwa i cechy w r. 1840:

bractwo św. Anny proboszczowi - 35 zł, organiście - 5 zł

bractwo literackie $\quad-36 \mathrm{zł}, \quad-5 \mathrm{zł}$

cech kowalski $\quad-12 \mathrm{zł}, \quad-5 \mathrm{zł}$

cech krawiecki $\quad-9 \mathrm{zł}, \quad-3 \mathrm{zł}$

cech kuśnierski $\quad-42 \mathrm{zł}, \quad-4 \mathrm{zł}$

cech szewski $\quad-36 \mathrm{zł}, \quad-3 \mathrm{zł} 15 \mathrm{gr}$

cech płócienniczy $\quad-21 \mathrm{zł}, \quad-2 \mathrm{zł} 10 \mathrm{gr}$

- WAP w Kielcach, Oddział Terenowy w Radomiu, akta Komisji Województwa Sandomierskiego i Rządu Gubernii Sandomierskiej 301, s. 389-394v 
kuśnierskiego Jan i Jadwiga Kwietniewicze 50 zł z legacji niejakiego Józefa Cielickiego. Suma ta została przejęta $\mathrm{z}$ rąk małżonków Lichockich, których cech skwitował. Suma została opisana na roli Kwietniewiczów. Prowizja w wysokości 3 zł 15 gr miała być płacona 11 grudnia, po święcie Niepokalanego Poczęcia NMP, pod groźbą utraty roli. W 4 lata później tenże Kwietniewicz odebrał jeszcze $50 \mathrm{zł} \mathrm{z} \mathrm{czynszem} 4$ zł. W r. 1792 małżonkowie Zwolscy przejęli od cechu kuśnierskiego z rąk małżonków Krzemińskich $40 \mathrm{zł} \mathrm{z} \mathrm{legatu} \mathrm{„pracowitego"} \mathrm{Józefa} \mathrm{Cielińskiego,} \mathrm{z} \mathrm{czynszem} 3$ zł płatnym na wigilię Bożego Narodzenia (24 XII). W r. 1794 małżonkowie Grudniewscy przejęli od cechu kuśnierskiego 60 zł z prowizją 4 zł, płatną nazajutrz po zaślubieniu Najświętszej Maryi Panny (22 I) za opis sumy na roli Zwolskich na Zagumniu.

W działalności kredytowej cechu kuśnierskiego uderzają dwie rzeczy: dowolność terminu płatności prowizji oraz sama wysokość tej prowizji ustalana raczej indywidualnie ( od $50 \mathrm{zł}-3,5 \mathrm{zł} \mathrm{i} 4 \mathrm{zł}, 4 \mathrm{zł}$ od $50 \mathrm{zł} \mathrm{i} 60 \mathrm{zł}$ ). Osoba legatora, pracowitego Józefa Cielińskiego, wskazuje, że legatów do cechu dokonywały również osoby spoza cechu, m.in. spośród poddanych chłopów ${ }^{106}$.

Dla cechów krawieckiego i zbiorowego zachowało się po jednym tego rodzaju dokumencie. W r. 1790 małżonkowie Niedźwieccy wzięli z cechu krawieckiego $50 \mathrm{zł}$ (prowizja $\mathrm{z}$ powodu zniszczenia dokumentu nieznana), opisując ją na domu, dwóch placach i rólce na Krzywdach, czynsz płatny na św. Barbarę (4 XII). W 1804 r. na podobnych jw. warunkach podjęli $100 \mathrm{zł}$ z cechu kowalskiego, rymarskiego itd. (czyli ze zbiorowego) małżonkowie Pazdrowscy ${ }^{107}$.

Powyższych transakcji dokonywano w magistracie za zgodą i w obecności starszyzny cechowej oraz w obecności władz miejskich, zwłaszcza wójta.

Działalność religijna cechów była więc w całokształcie ich działalności bardzo poważna, co wynikało z przekonania, że człowiek jest na tej ziemi tylko pielgrzymem, zmierzającym do innej, wiekuistej Ojczyzny, należy więc przede wszystkim dążyć do osiągnięcia zbawienia i nawzajem sobie w tym pomagać108.

106 Por. legator do bractwa literackiego, poddany z Krzykóz Marcin Krajewski. Wszystkie powyższe, jak i poniższy dokument to wyderkaufy z ksiąg miejskich koprzywnickich, z których wyciągi znajdują się w archiwum parafialnym w Koprzywnicy.

107 Bibl. Narod., mk 18218.

108 Por. zakończenie statutu cechu płócienniczego - H. Ruciński, Ustrój cechów rzemieślniczych w Koprzywnicy do 1795 roku, „Zeszyty Naukowe Filii Uniwersytetu Warszawskiego w Białymstoku", z. 19, Humanistyka, t. IV, Dział H - Prace historyczne, Białystok 1977 , s. 73. 